\title{
WHAT DOES IT TAKE TO BE AN AMERICAN?
}

An American is someone who is either born in the United States, or is a permanent resident or a citizen and has developed an attachment to the USA through his/her length of stay in the country. Anthony Smith observed that, in the western model of national identity, nations are seen as cultural communities whose members are, if not homogeneous, united by common historical memories, myths, symbols and traditions. Even when new immigrant communities equipped with their own historic culture and traditions have been allowed into a host country, it has taken several generations before their descendants are absorbed into the circle of the 'nation' and its historic culture. Smith also identified land or attachment to land, its rivers, coasts, lakes, mountains and cities as important. These attachments become 'sacred' as people live in a place for generations, and this bond can create people's national identity. ${ }^{1}$ Kwame Appiah noted, however, that identity is not determined by a specific amount of time or number of generations, but how quickly one can adapt to the host country's way of life. That is, according to Appiah, Americans are people who speak the English language and know something about American sports such as baseball and basketball. Americans are also familiar with American consumer culture and brands such as Coca-Cola, Nike, Levi-Strauss, Ford, Nissan and GE. They have seen Hollywood movies and know the names of some actors, and 'even a few who watch little or no television can probably tell the names of its "personalities"'.2

Speaking of the positive side of American society, Selcuk Sirin and Michelle Fine observed that Muslims in the United States have one of the highest rates of citizenship in a nation that embraces diversity and has the reputation of being a 'melting pot'. America allows the coexistence of many cultures such as Irish Americans and African Americans. ${ }^{3}$ Appiah pointed out that the US is a country where citizens are remarkably diverse with respect to religious belief 
and practice and, nevertheless, share in the public world. 'Orthodox Jews and devout Sunni Mulims walk around together on 34th Steeet in New York City, and they don't attack one another. If they do, the state knows what to do about it.' ${ }^{4}$ Similarly, American citizens with diverse backgrounds exercise their voting rights and enjoy the 'democratic and judicial processes of a liberal society'. 5 Some scholars, however, believe that since $9 / 11$ and the enactment of the Patriot Act in October 2001, some Muslims have suddenly become regarded as the 'other'. ${ }^{6}$ Tony Gaskew and Louise Cainkar observed that it has become more challenging for Muslim youth to negotiate their identities because they are perceived as a potential threat to the wider society. ${ }^{7}$

In this chapter I examine why and how the participants in this study constructed their identity. Firstly, I discuss their responses to questions about their identity (summarised in Table 3.1). Secondly, I examine the patterns of multiple and dual identities and determine the factors that may have dictated these identities. Thirdly, I evaluate why some respondents chose to have a distinct identity: collective national, ethnic or religious, and finally I discuss whether sport (an integral part of biculturalism) had any impact on the participants' identity. I have discussed the importance of biculturalism in youth identity in the Introduction and Chapters 1 and 2. Most of the participants of this study were bicultural. That is, they spoke the English language, listened to western music and watched English-language television programmes; some read English-language novels, engaged in contemporary politics (further exhibited in Chapters 5 and 6) and watched and participated in mainstream sports; and they also retained all or some of their ethnic and religious practices.

Table 3.1 shows that 58 participants spoke of their multiple identities (which sometimes included religion), 144 participants spoke of their dual identity (with or without the mention of Islam); 51 spoke of their single ethnic identity; 65 spoke of their collective/group identity; 36 participants mentioned only their religious identity; 19 participants spoke of their American identity; and 6 participants had other identities. In the next and subsequent sections, I examine the patterns of identity and try to find out why the participants discussed their identity/identities in a particular manner and to understand their placement in the American society. ${ }^{8}$

\section{Multiple identities: identity is contextual}

In this study, fifty-eight participants (of whom forty-three always added Islam and fifteen sometimes added religion) spoke of their multiple identities. On multiple identities, Amartya Sen observed that in everyday life a person sees himself belonging to various groups through his citizenship, residence, country of origin, gender, class, profession, food habits, interest in music and sport and social commitments. Each of these collectivities to which this person simultaneously belongs gives him a particular identity. So a person can live his or her 
Table 3.1 Patterns of identity

Questions asked: How would you define your identity/sense of belonging? Would you consider yourself American? Or Afghan/Iraqi/Moroccan or Muslim, etc.?

\begin{tabular}{|c|c|c|}
\hline $\begin{array}{l}\text { Number of } \\
\text { participants }\end{array}$ & Responses & Key points \\
\hline $\begin{array}{l}16 \text { male, } \\
27 \text { female }\end{array}$ & $\begin{array}{l}\text { Multiple identities: } \\
\text { national, ethnic/racial } \\
\text { and religious }\end{array}$ & $\begin{array}{l}\text { Muslim first then African American; Muslim } \\
\text { first and foremost, then Arab American; } \\
\text { South-African American Muslim; Muslim Sri } \\
\text { Lankan American; Muslim Black Haitian; } \\
\text { Muslim American of Yemeni descent; } \\
\text { 'American Muslim who came from Palestine'; } \\
\text { 'Muslim first because I have memorised } \\
\text { the Quran, then white and then Pakistani'; } \\
\text { Muslim American Egyptian; Afghan American } \\
\text { Muslim; Muslim Pakistani American; Muslim } \\
\text { American Guyanese. }\end{array}$ \\
\hline $5 \mathrm{~m}, 10 \mathrm{f}$ & $\begin{array}{l}\text { Multiple identities } \\
\text { (with or without the } \\
\text { mention of religion) }\end{array}$ & $\begin{array}{l}\text { Few identities; Muslim multi-racial; Canadian } \\
\text { American Somali; Pakistani German } \\
\text { American; Greek Italian Muslim American; } \\
\text { Arab Italian Muslim American; Muslim } \\
\text { Ethiopian American, a woman; Miami Cuban } \\
\text { Turkish American; 'Muslim first, three-fourth } \\
\text { American, one fourth British of Burmese } \\
\text { heritage'; 'I am mostly American, I am } \\
\text { Muslim, half Arab, and I am also something of } \\
\text { a nerd'; French, American, Arab and Muslim. }\end{array}$ \\
\hline $21 \mathrm{~m}, 23 \mathrm{f}$ & $\begin{array}{l}\text { Dual identity: national/ } \\
\text { ethnic and religious }\end{array}$ & $\begin{array}{l}\text { American Muslim; Muslim American; just } \\
\text { Muslim from Sudan; Albanian Muslim; } \\
\text { Muslim Guyanese; Muslim Palestinian; Indian } \\
\text { Muslim; Muslim Yemeni; Muslim Algerian, } \\
\text { Bengali Muslim; Muslim Egyptian; Muslim } \\
\text { first then Pakistani. }\end{array}$ \\
\hline $49 \mathrm{~m}, 51 \mathrm{f}$ & $\begin{array}{l}\text { Dual identity: national } \\
\text { and country of origin }\end{array}$ & $\begin{array}{l}\text { American Iranian; Palestinian American; } \\
\text { Pakistani American 50:50; ‘American Bengali } \\
\text { but my mom says that I have to be only } \\
\text { Bengali Muslim'; } 99 \text { per cent American } \\
\text { and } 1 \text { per cent Pakistani; American Desi; } \\
\text { Guyanese American; American Tanzanian; } \\
\text { 'half American and half Puerto Rican'; Syrian } \\
\text { American; Iraqi American; Trinidadian } \\
\text { American; American Yemeni; Lebanese } \\
\text { American; Bengali English. }\end{array}$ \\
\hline $4 \mathrm{~m}, 2 \mathrm{f}$ & $\begin{array}{l}\text { Collective identity: } \\
\text { African American }\end{array}$ & $\begin{array}{l}\text { New migrant visibly white from Algeria, } \\
\text { second generation from Sudan; great- } \\
\text { grandparents from Louisiana, traditional } \\
\text { African American. }\end{array}$ \\
\hline
\end{tabular}


Table 3.1 (continued)

Questions asked: How would you define your identity/sense of belonging? Would you consider yourself American? Or Afghan/Iraqi/Moroccan or Muslim, etc.?

\begin{tabular}{|c|c|c|}
\hline $\begin{array}{l}\text { Number of } \\
\text { participants }\end{array}$ & Responses & Key points \\
\hline $16 \mathrm{~m}, 19 \mathrm{f}$ & $\begin{array}{l}\text { Collective identity: } \\
\text { Arab American }\end{array}$ & $\begin{array}{l}\text { 'Arab American, if people want to know } \\
\text { which country I'm from, then I will tell } \\
\text { Palestine'; 'Arab American but } 75 \text { per cent } \\
\text { American'; 'Arab American: } 75 \text { per cent } \\
\text { Palestinian and } 25 \text { per cent Colombian'. }\end{array}$ \\
\hline $5 \mathrm{~m}, 9 \mathrm{f}$ & $\begin{array}{l}\text { Collective identity: } \\
\text { wider ethnic/racial } \\
\text { group }\end{array}$ & $\begin{array}{l}\text { Only Arab; Arab Muslim; more Arab; African } \\
\text { Muslim; American Kurdish; half African } \\
\text { American and half Puerto Rican. }\end{array}$ \\
\hline $2 \mathrm{~m}, 5 \mathrm{f}$ & $\begin{array}{l}\text { Collective identity: } \\
\text { dual nationality/ } \\
\text { ethnicity }\end{array}$ & $\begin{array}{l}\text { Pakistani Kashmiri; Yemeni Arab, Filipino } \\
\text { Egyptian; part Pakistani, part Cuban. }\end{array}$ \\
\hline $0 \mathrm{~m}, 3 \mathrm{f}$ & $\begin{array}{l}\text { Collective identity: } \\
\text { regional }\end{array}$ & $\begin{array}{l}\text { Middle Eastern; south Asian Kashmiri; Middle } \\
\text { Eastern European. }\end{array}$ \\
\hline $16 \mathrm{~m}, 35 \mathrm{f}$ & Single ethnic identity & $\begin{array}{l}\text { Just Afghan girl; still Moroccan; just Pakistani, } \\
\text { pure Bengali, Lebanese } 100 \text { per cent; only } \\
\text { Guyanese; Iraqi; Yemeni; 'still connected to } \\
\text { Somali tribe'; ' } 100 \text { per cent Turkish'; 'I don't } \\
\text { want to be an American'; 'very Palestinian, } \\
\text { very human'. }\end{array}$ \\
\hline $18 \mathrm{~m}, 18 \mathrm{f}$ & Single religious identity & $\begin{array}{l}\text { Just Muslim; practising Muslim in America; } \\
\text { 'Muslim but my mom yells that I have to be a } \\
\text { Bengali'; 'Muslim and servant of Allah'; 'I'm } \\
\text { a man of God (Allah); 'I'm Muslim, kind, } \\
\text { loving and friendly'; 'I don't consider myself } \\
\text { as African American nor solely American. } \\
\text { American history is full of oppression. I'm } \\
\text { only Muslim'. }\end{array}$ \\
\hline $11 \mathrm{~m}, 8 \mathrm{f}$ & $\begin{array}{l}\text { Single national identity: } \\
\text { American }\end{array}$ & $\begin{array}{l}100 \text { per cent American (Pakistani origin); } \\
\text { only American (West African origin); 'Most } \\
\text { of the time I feel American' (Bangladeshi } \\
\text { origin); 'My mother and grandmother } \\
\text { were Native Americans'; American/African } \\
\text { American convert; only American (Yemeni } \\
\text { background). }\end{array}$ \\
\hline $4 \mathrm{~m}, 2 \mathrm{f}$ & Other & $\begin{array}{l}\text { 'My identity is my family'; human being first } \\
\text { and foremost; citizen of the world; 'I used to } \\
\text { say that I'm only Muslim'; 'American history } \\
\text { is all of oppression and I am now reconciling } \\
\text { my identity'. }\end{array}$ \\
\hline
\end{tabular}


life through multiple identities. ${ }^{9}$ In this study, I found that, when participants spoke of their multiple identities, they spoke of certain issues from their lived experience such as experiences at workplaces or educational institutions. For example, Ameena (female, 20, US born, Egyptian origin) comfortably spoke of her multiple identities:

I feel I am part of everything. I identify myself as an American, an Arab, a Muslim and a female and so there are a lot of identities that I carry with me every day. I can't say that one takes precedence over the other. (Interview, Florida, March 2010)

On her Arab identity, Ameena said at home she spoke Arabic with her parents, had Middle Eastern cuisine, and enjoyed listening to Arabic music. She said, 'So I guess the cultural aspect of it makes me Arab.' On her American identity, Ameena said, 'My first language is English and I speak it every day at school. I study it, and I listen to all the English songs, so that also makes me American.' She continued: 'My everyday religious practices, wearing the hijab, praying, fasting, make me a Muslim.' On her feminine identity, Ameena said:

I definitely connect with all the women's issues that are going on around the world, even in the US too. Especially with my job here, we do address women's issues, you know, domestic violence. And even at the mosques that I attend, they are always seeking for people to help women in need financially or if they have psychological needs, so there is always a sister in the community that needs another sister to help her. So I always try to help them.

On her sporting interests, Ameena said that she watched the Super Bowl. She watched her brothers play American football in high school. She also followed the World Cup and the African Cup, and she played soccer and volleyball with her friends at the weekend. She added, 'I watch basketball too and since I live in Miami and I go to school in Miami, I support the Miami Heat. They are a basketball team.' Through her office, Ameena took an active part in raising funds for the earthquake victims in Haiti, and she was appreciative of the celebrities who were donating and contributing to that cause. Ameena concluded, 'I really commend them for that and going there personally and helping and building homes despite their busy and fancy life. They are taking time, you know.'

Sen wrote that identifying with others, in various different ways, can be extremely important for living in a society, and multiple identities involve loyalties. For example, in Ameena's case, her multiple identities revealed her loyalty to various categories: ethnicity/race (Arab), citizenship/nationality (American), religion (bijab), local/state (Miami Heat), feminism (helping women) and humanitarianism (Haiti). Sen said, 'Belonging to each one of the membership groups can be quite important, depending on the particular context.' However, he noted that 'when they compete for attention or priorities over each other, 
the person has to decide on the relative importance to attach to the respective identities, which will, again, depend on the exact context' ${ }^{10}$ That is, if Ameena chose her exclusive American identity over her Arab identity, it would be relative to her experience of a certain event.

The second participant, Fariha (female, 16, US born, American-Palestinian background) said, 'I am mostly American, half Arab, and I am Muslim and I am also something of a nerd, I guess' (interview, Michigan, May 2010). Fariha was not interested in sport, but she liked walking and dancing and wanted to try swimming but thought that her hijab was a barrier to such sport. Fariha's American and Muslim identities were revealed when she criticised Michael Roskin, the author of a school textbook she was using for a comparative study of government. ${ }^{11}$ Fariha observed, 'Roskin takes a strong American stand and is basically comparing them [other governments] to our own government and the author gives the impression that all countries, even the UK and Germany, they are all inferior to us.' Fariha's reference to 'our government' and 'inferior to $u s$ ' revealed her Americanness. But her Muslim identity came to the fore when she said:

There are lot of things that just strike you, it's all subtle, and I think that when you're talking about Muslims, I remember he [Roskin] had a whole page on whether Saddam was incompatible with the modern world and when he was discussing the Iranian government, it's just like a lot of little things like that. And I remember once, for instance, he said Muslims practice honour killing and wife beating.

Since Fariha mentioned Roskin's book, I read it to see what information the author provided to his readers (particularly high school and university students). I found that Roskin has indeed made stereotypical comments in his book. For example, he wrote, 'As in Britain and France, some Muslims want Islamic family law to govern such traditional practices as wife beating, instant divorce, and "honor killings" of unchaste women.' Next, Roskin said, 'Muslim families have many children, sometimes eight or more. Some Russians fear that their stagnant numbers will be swamped by a tide of inferior peoples.' Roskin continued, 'In some Muslim countries (not Iran), such customs as the seclusion of women, the veil, and female genital mutilation are pre-Islamic and were absorbed by Islam. ${ }^{12}$

In my previous research, I have addressed how some media sources label some cultural practices, such as honour killings, as an exclusively Muslim practice, but honour killing is very much practised by some non-Muslims in places such as India. Similarly the practice of female circumcision is a cultural practice in some African countries. ${ }^{13}$ Identifying certain cultural practices in textbooks as the 'Muslim other' is not helpful.

Finally, Murad Ali (male, 18, overseas born, Egyptian background) said that he was 'an Egyptian, American and a Muslim'. He explained, 'My culture, 
my originality, my parents, I'm born in Egypt, I'm naturally Egyptian. I could say I am American because I was able to change my mindset .. . I'm more open minded.' Murad Ali was very much into sport. He revealed his American connection when he said:

I don't know why America is trying to help other countries when it's so screwed up itself right now. You have so many illegal immigrants destroying the country, it's half Hispanic. The population of Hispanics is growing so rapidly. And they're living on the government's money so the government is paying for them to have more kids and repopulate the country and that's stupid, that's pointless. I'd rather have 100 educated people than 10,000 retards. (Interview, New York, January 2010)

Murad Ali was concerned that if the number of uneducated people increased, it would be a burden on the US government. ${ }^{14} \mathrm{He}$ worked part time in a grocery shop and he expressed his concern about how some people (including Muslims) drove expensive cars such as BMWs and yet bought food with food coupons, thereby 'cheating the system [the government]'. Even though Murad Ali spoke of his multiple identities, his interview conversation mostly revolved around 'being a good American citizen' and 'not cheating the system'.

\section{Dual identity}

\section{Identity is negotiable}

A plurality of participants (144) cited their dual or hyphenated identities, which meant that they were simultaneously identifying with two cultures. Homi Bhabha observed that people accepting two cultures are flexible in negotiating every situation, thereby locating their culture in a 'third space'. ${ }^{15}$ Sometimes one's response can be deliberate, sometimes spontaneous or unintentional. In a duality, one's cultural mind can crystallise while responding to certain events. As Bhabha said, 'The process of cultural hybridity gives rise to something different, something new and unrecognisable, a new era of negotiation of meaning and representation. ${ }^{16}$ For example, a participant in this study, Sami (male, 17, US born, Sudanese origin) said that his identity was 'just Muslim from Sudan'. He was born in the USA but had visited Sudan many times. He was also involved in Muslim community services and liked travelling and sport.

Sami's identity meant that he was culturally a Sudanese Muslim. He observed the Muslim way of life (prayers, fasting, halal food, no alcohol) and felt connected to Sudan through his frequent visits there, together with Sudanese cuisine and the Arabic language. Sami's Sudanese identity was reflected when he spoke of the Sudanese president, Omar Bashir: 'A lot of media have gone against Sudan and overexaggerated that he was responsible 
for killings and all this raping and stuff but I guess Omar Bashir handled it well.' When I asked him about the teddy bear incident in Sudan, Sami replied:

About the British lady naming the teddy bear Muhammad ... They [the Sudanese government] shouldn't have put her in jail ... because she's not Muslim so she doesn't know what's harram. She did that by an accident. All they had to do was explain to her and maybe if they want emigrate her back to her country. (Interview, New York, January 2010)

In November 2007, a 54-year-old British international school teacher at Unity High School in Sudan, Gillian Gibbons, was charged with 'inciting religious hatred'. In Sudan, where the legal code is based on shariah law, it is considered an insult and illegal to give the name Muhammad to an inanimate object. The charge was that by giving this name to a toy bear in her second-grade class, Ms Gibbons insulted Islam. She was arrested in Sudan and faced the prospect of up to six months in jail, a fine and forty lashes for blasphemy. Later, Ms Gibbons was spared the lashes, and the president of Sudan pardoned her after two British Muslim members of the House of Lords, Baroness Warsi and Lord Ahmed, pleaded for clemency on her behalf. ${ }^{17}$ So Sami's 'third space' was a negotiation or reconciliation with western culture (though he did not mention his American connection) which helped him to think rationally on the matter.

\section{Identity is situational}

The second participant, Karishma (female, 15, US born, Sudanese origin) said that she was 'Sudanese American':

I'm in the middle, half and half. I really love my Sudanese culture - it's beautiful. I think it's very unique and I like to be a unique person. But also since I'm in America I feel like I'm almost American; it's alright, I guess. (Interview, Massachusetts, November 2009)

Karishma related her Sudanese culture to her food and language. Karishma's American side was revealed when she said, 'I like to play basketball, I like to watch football. I'm trying to learn how to play soccer ... I like the Patriots of course.' Karishma's identity appeared to be situational with an intense need to fit in to American youth subculture. ${ }^{18}$ When I asked Karishma about her lip ring, she replied, 'I don't want people to think all Muslims are crazy, like all they do is pray, pray and pray. I want to show them a different side. We can get piercings; we can do all this stuff in Islam.' Karishma went on to criticise the American media:

American media it's not great like I would expect it to be. They keep pushing on Muslims, saying that they're all bad, and there were a couple of incidents - like we 
were going on the train and then, you know, non-Muslims kept saying 'Oh, Muslims are terrorists' and I don't really like to be called that at all.

Karishma's experience coincided with and may have arisen from news that the alleged terrorist Tarek Mehanna was arrested in Boston in October 2009 (see further discussion in the Arab American section of this chapter). Karishma continued telling her experience of racial profiling:

I don't think it's the Muslims' fault ... I think it's just the media. Like if someone wearing hijab or a man with a really long beard, if you go to the airport ... I remember we went to the airport and they always have to check us, as if we had a bomb in our pockets or something. We would go through the detectors and the alarm doesn't go off but then they have to check us. I think if we didn't wear hijab or if we cut our beards that wouldn't have happened in the first place.

Experiences of racial profiling were discussed by other participants whose identities varied from single to dual or collective (discussed later). Apart from the concept of racial profiling, in this study I found that the desire to fit in ('a third space') with the broader community was a common attribute of Muslim youths.

\section{Identity is spontaneous}

Deeba (female, 25, US born, Iranian background), identified herself as American Iranian. Deeba was a sports fan and watched soccer, American football and basketball. Her favourite teams were the New York Knicks and the Boston Celtics. Deeba enjoyed swimming and gymnastics until the age of twelve, less so when she started wearing her hijab. However, she continued to play soccer in her hijab. Though born and raised in the US, Deeba was aware of the bitter relationship between Iran and the USA since the downfall of the Shah of Iran and the rise of the Islamic Revolution. Deeba's 'third space' appeared to be spontaneity. When I asked Deeba how she felt when Iran was so much in the news, she replied:

I kind of find it really interesting with politics and it's been over 30 years, how much the Iran and American relationship is. But you know, both countries are very smart about their tactics with each other. If one says something, the other has to retaliate and so on ... Because most of the Iranian people and the American people just absolutely love each other ... Yeah, it's the government. (Interview, Massachusetts, December 2009)

Deeba also observed that negative American news was highlighted in the Iranian newspapers and vice versa. For example, the American media would be 
critical of Iran for its abuse of human rights against homosexuals. But negative news about Americans does not get equal space in the US media:

If you open up the newspapers in Iran, you know the doctor that they killed, for example, in Atlanta, Georgia some time ago, because he had an abortion clinic; it wasn't a huge deal in the United States [but was a big news story in Iran]. They kind of put a damper on it, but what I'm saying is that both governments [and the media] know how to play the cat and mouse.

In 1973 abortion was legalised in the USA. Since then some anti-abortion activists have resorted to violence against abortion clinics and doctors. But this information (as Deeba observed) does not capture news headlines or is not reported as continuously in the US as other news. Since 1993 four American medical doctors who conducted abortions have been killed by anti-abortion activists: David Gunn and John Bayard Britton in Pensacola, Florida; Barnett Slepian in Buffalo, New York; and George Tiller in Wichita, Kansas.

Iran featured in the US (and other) media over the controversial re-election of President Mahmoud Ahmadinejad in June 2009. His opponent, MirHossein Mousavi, issued a statement saying that the election results were a 'charade', and urged his supporters to fight the decision but without any acts of violence. This resulted in massive post-election street protests. However, the powerful Iranian Guardian Council formally certified the re-election of President Ahmadinejad to a second four-year term, saying there was no validity to charges of voting fraud. ${ }^{19}$ Perhaps Deeba's Iranian identity persuaded her to take the side of the Guardian Council when she said that there is also corruption in the US election process but it was never in the news:

Yeah, the old [guard], I'm not very familiar with Iranian politics ... But the funny thing was ... I started asking myself how come five years ago I didn't go around saying 'Where did my vote go for John Kerry [opponent of George W. Bush]?', you know?

The 2000 US presidential election was controversial. In this election, George W. Bush ran on the Republican ticket against Democratic candidate Al Gore. The election was flooded with allegations of voter fraud and disenfranchisement, particularly in Florida. Eventually, the US Supreme Court gave the state of Florida's electoral votes to George W. Bush. ${ }^{20}$ This meant that, although Gore held a slim popular vote victory of $543,895(0.5 \%)$, Bush won the electoral college 271-266, with one Al Gore elector abstaining. The 2004 US presidential election (like 2000) was also decided by one state. Ohio's twenty electoral votes gave President Bush his margin over his Democratic Party opponent, Senator John Kerry. ${ }^{21}$ Deeba's hometown was in Ohio so her opinion on the 2004 election result may have some validity. Through her Iranian 'self' 
Deeba thought at least there was a democratic process in Iran as demonstrated by the Iranian public protests on the streets, but when there was a reasonable doubt over George W. Bush's election results, Americans were reluctant to go onto the streets and protest:

I came to ask myself, why didn't Americans, why didn't we pour out onto the street and ask the United States government 'Where did my vote go?' But at the same time it goes to show how far Iran has come, that [this] generation was able to go out onto their street and ask those questions.

The remark 'Why didn't we pour out into the streets?' reflect Deeba's Americanness, though she was constantly going back and forth with her comparison of Iran with the USA.

On the topic of homosexuality, Deeba commented:

What was funny was when President Ahmadinejad had mentioned that we don't have any gay people in the country, the next day on NPR all these gay people are coming out and they're saying 'Yeah, I'm gay, I'm gay'! So that's the thing, it's like okay if there are homosexuals in Iran, maybe ten years from now they might be open about it ... it goes back to even like ten years ago as an American if you were gay ... it wasn't even a spoken thing in the United States.

It is also interesting to note here that Deeba used 'we' to refer to Iranians, which was obviously indicative of her collective Iranian identity.

In 2007 during his visit to the USA, President Ahmadinejad gave a talk at Columbia University in New York. He proposed a conspiracy theory when he asked the university audience to look into 'who was truly involved' in the 9/11 terrorist attacks, defended his right to question established Holocaust history, and denied there were gay Iranians. He elicited laughter and boos from the audience when he said, 'In Iran, we don't have homosexuals, like in your country. ${ }^{22}$ Though Deeba spoke of her identity as Iranian American (and defended her Iranian identity), she spoke of her ordeal of 'being Muslim and American' at airports. She said that in the USA 'they would stop me and say "Okay, can you step over here? We have to search you." Then they have this glass-like box and you go in there so they can see you through the machine.' However, in a Muslim country, Deeba found that they practise 'an extreme form'. She said:

When I was in the United Arab Emirates in the airport ... and it's a Muslim country, technically, and they [female security] pulled me aside and they told me to take off all my clothes ... Again being Muslim, being American, you're sandwiched in between because if you go with your American passport to a Muslim country they're going to treat you the same way that they're being treated here ... So it makes the situation harder but, like I say, you just have to take it with a grain of salt. 
However, the case in point is that identity is always in motion, so the subconscious 'self' may spark up as a spontaneous reflection when one's country of origin is questioned or ridiculed. Also, certain aspects of identity that were not explicitly spoken about (for example, Karishma and Deeba's Muslim identity) came up in the conversation when identity was in crisis, particularly at airports.

\section{Collective identity: African American identity}

Francesca Polletta and James Jasper observed that collective identities can be expressed in cultural materials such as common names, narratives, symbols, speech patterns, clothing, customs and traditions. Cultural collective identities can also be formed beyond any common cultural materials through emotional connections (in this case with the African continent). And they may be imagined rather than experienced directly. They are fluid and relational and emerge out of a desire to discover pre-existing bonds, interests and boundaries. It is a process by which individuals try to make sense of broader social interests. ${ }^{23} \mathrm{Kwame}$ Appiah observed that the 'African American identity (like all other American ethno-racial identities) is centrally shaped by American society and institutions: it cannot be seen as constructed solely within African American communities, any more than whiteness is made only by whites' ${ }^{24}$ Appiah observed that an oppositional character/institution or an 'opposing self' is necessary for the formation of an identity. So a conventional 'white' American society would produce an African American community. Though the African American community has moved on since the Black Power and Civil Rights movements, ${ }^{25}$ several researchers have shown that some African Americans still occupy a marginalised position in American society. ${ }^{26}$ In my study, however, the participants who identified themselves as African Americans revealed their diverse connections.

\section{Emotional attachment}

A first-generation participant, Mesbah, of Algerian background (male, 30, overseas born, educator) migrated to the USA in the 1990s, and he looked visibly 'white', but defined his identity as 'African American I would say, even though I'm not dark. I feel like I belong to Africa more than I belong to Algeria itself' (interview, Massachusetts, November 2009). Mesbah was religious. He was not interested in sport but he listened to religious music, such as nasheeds. He said, 'The one I listen to, if I have time of course, I don't know if you know Mishary Rashid Alafasy from Kuwait.'

Mesbah identified himself as 'African American' because he felt connected to the African continent but when he spoke of nasheeds he preferred a Kuwaiti singer. It appeared that he was comfortable with a transnational ummah connection. However, Mesbah was not alone. I found that a few second-generation young Americans such as Somali Americans would define 
themselves as 'African Americans', though they were non-traditional African Americans (with no enslavement history in the USA). The US census form has 'African American' in the 'race' category, so some people may classify themselves accordingly. Also, the new immigrants of African background may feel comfortable with their collective African identity because of their diasporic placement in America. They may have an emotional attachment to Africa and a wish that one day they will return 'home'. ${ }^{27}$

\section{Racelcolour}

A third-generation participant, Adam, of Jamaican background (male, 16, US born), said that his African American identity was linked to his race: 'I was born in America and so were my parents, but both of my grandfathers were born in Jamaica. My African connection is because of my skin colour.' Next, he expressed his connection to sport through his race:

I have fondness for football as well but I much prefer basketball. Oh, Celtic, Boston Celtics! Because they have three of my favourite players on that team, yes. Kevin Garnett, Paul Pierce and Ray Allen, and ... and a fourth is Rajon Rondo. They're all African American. (Interview, New York, November 2009)

At the time of the interview Adam looked Muslim because he was wearing the kufi (though it is a traditional cap for men in west Africa irrespective of their religion). Adam said that he attended a madrasab when he was young, and when he was not attending school (during school break) he attended an African American mosque during Ramadan and for Friday prayers. About his friends, Adam said:

Well, I have friends who are Arab, I have friends who are from Pakistan, I have friends who are African American, I have friends who are Hispanic. I have friends who are Chinese and I have friends from all over.

Some social identity theorists state that external factors (power, politics of difference) or internal factors (similar ingroup feeling) can lead to the construction of one's identity. ${ }^{28}$ In Adam's case, his roots (heritage) and visibility (blackness) played leading roles in the construction of his identity. Also, in his interview, Adam did not specifically mention if he had any white American friends. This factor could have impacted on his restricted African American identity.

\section{Religion}

Mariyam, of African American origin (female, 22, US born), said that her identity was African American. However, most of the time during her interview 
she spoke about Islam and how to be a 'good Muslim'. Mariyam converted to Islam because she intended to marry a Muslim man. The marriage did not take place but she was happy that she had converted. Mariyam wore the hijab. She said that she used to be a cheerleader and also played soccer but now she has abandoned playing soccer because in some sports, she says, 'You have to shake hands with men.' She liked swimming and was a fan of the New England Patriots American football team and the Boston Red Sox for baseball. On music, Mariyam said:

Music is harram and I'm trying to stop but there's one CD I keep listening to. The name of this group is New Radicals and the name of the song 'You Get What You Give'. It's about rich people always dressed up and they have closed hearts, they don't care ... So this is the music I listen to and I like it but I'm trying to really cut back because there's maybe two swears in it ... He says the A-word for your butt. [The song includes the words 'This whole damn world can fall apart ... We'll kick your ass in']. (Interview, Massachusetts, November 2010)

According to Mariyam (and a few other participants in this study) listening to music is harram. Mariyam said, 'Music is harram because Satan made the trumpets.' The topic of listening to music, however, has been contentious among Muslims. The British pop singer Yusuf Islam, formerly known as Cat Stevens, stopped singing shortly after his conversion to Islam in 1977 . He was told by his Islamic teachers that music 'represents frivolity and time wasting', but since then he came to understand that music can serve a purpose. He thought that music can be healing when he noticed Bosnian Muslims, who had lost everything else during the war in Yugoslavia, listened to music to maintain their sanity. ${ }^{29}$ Whereas some Muslims, such as the mystical Sufi sect and the Turkish 'whirling dervishes', consider music to be part of 'the very essence of Islam', others, for example ultra-conservative Muslims such as the Salafis, feel it is 'intoxicating' and distracting from meditation and spiritual concentration (I discuss music further in the Conclusion). Mariyam had some ultra-conservative Muslim friends from an Arab background, so she was perhaps influenced by their thoughts.

\section{Visibility: men}

Ehsan, of African American/Native American/Spanish background (male, 19, US born), was bearded and visibly Muslim; he wore the white Arab jilbab and kufi. Ehsan identified himself first as an African American, and second as a Muslim American. Ehsan was not a sports fan but he listened to music. 'Actually hip-hop, I also like a little soft rock, alternative rock, classical, R\&B. Yeah, I do listen to hip-hop.' Ehsan spoke passionately of Palestine, which I thought was an awkward African American connection: 
I love the country Palestine. I feel for that country so much basically because [of] all the things that they're going through. Actually, my best friend, he's Palestinian. So he's also led me to love the country even more, just because of how he loves it and his passion for his country. (Interview, Michigan, April 2010)

Ehsan's Palestinian connection came through his social group, especially a college friend who was a Palestinian. Ehsan's friend visited Palestine and shared with him the difficulties the Palestinians face in their everyday lives. And Ehsan revealed his Muslim identity when he said:

Being Black and Muslim can be difficult. So I can walk down the street here [in a Muslim majority suburb] with a turban and my thob or whatever, and I feel comfortable, I feel safe. But walking down my street, because there are not very many Muslims on the side of town where I live, it's kind of difficult because they'll say something like 'Why is that on your head?' or 'Terrorist' or things like that.

The Mosque Study Project of American mosques in 2000 found that African Americans comprised 63 per cent of the converts to Sunni Islam and 68 per cent of those African American converts were male. ${ }^{30} \mathrm{~A}$ few other African American participants in this study who were visibly Muslim said that they were often misunderstood by the wider society because of their colour and Islamic visibility. In his study on African American young Muslims, Richard Brent Turner observed that since 9/11 the mainstream backlash against Muslims has also been directed against African Americans. However, the postSeptember 11th media coverage has been focused on the immigrant communities, particularly Middle Eastern people. The social and political perspectives of African American Muslims, who constitute roughly 30 per cent of regular mosque participants, have largely been ignored. ${ }^{31}$

\section{Visibility: women}

Aisha, of an African American/Native American background (female, 33, US born), identified herself as 'Black American Muslim'. Aisha converted to Islam through marriage. Regarding this conversion Aisha says, 'I had no idea about Islam ... And how I came to din [faith] was [through] my [former] husband ... I heard him call the azan, alhamdulillah, I took my shahada that day and was covering that same day.' Aisha was a single mother of four children, and she said that she was not a TV person, 'I'm more of a movie person but I am a writer (writing a book)'. Aisha thought that being black and Muslim was difficult:

I suffered a lot because of Islam. Where I worked at the time ... when I first became Muslim and I started covering, the first thing my boss said was, 'How long are you 
going to wear that thing?' And I said, 'What thing? . . . This is a part of who I am ... and I've been working for your company as an accountant for seven years, I'm still the same person ... I f feel like you're starting to discriminate against me and if that's discrimination then I need you to talk to my lawyer.' (Interview, Virginia, December 2009)

Aisha continued, 'And if I may add, there is prejudice even in Islam.' She talked of her experience with the mainstream Sunni Muslims:

You can take this as my opinion, a Pakistani Muslim who won't accept a black Muslim or don't think that you should even be Muslim, so that's very difficult. I've experienced every day and even during Ramadan ... I was in the mosque at Ramadan to serve the people to feed them and, alhamdulillah, Allah made a way for me to do that, but because I was black some people wouldn't take the food from me.

When I asked Aisha about her identity, she replied:

We went from being coloured to black to African American; we went through all these changes of 'who we are'. It's one thing to be an American; if you're American and non-Muslim it's pretty much accepted. To be a black American is different, it's several variances. To be a black American is very difficult even before Islam. It's even more difficult being American, black and Muslim. I've added not only that I'm an American or black American but now I'm a black American who covers and is Muslim.

In her study on Muslim women of South Asian and African American backgrounds, Jamillah Karim found that sometimes African American Muslim women (and men) are forced to isolate themselves from South Asian Muslims because of the latter's lack of acceptance of the former. African American Muslims have been historically stigmatised as having low educational levels, living in poor neighbourhoods, and being unemployed or underemployed, so this distances them geographically from South Asian or other Muslims. Typically, these African Americans choose to pray in African American mosques 'not because they feel excluded from immigrant mosques, but because they prefer a space that radiates distinctly African American Muslim heritage'. ${ }^{32}$ There is also a general consensus among African Americans that immigrant Muslims are obsessed with the ordeals of their fellow Muslims in Iraq or Afghanistan and unsympathetic to the plight of African Americans in terms of poverty and their overall marginalised position in American society. ${ }^{33}$ However, Aisha was educated and had the confidence to integrate into the immigrant Muslim community, even though she faced resistance from some of them. 


\section{Collective identity: Arab American identity}

Participants in this study with an Arab heritage defined themselves either as 'Arab' or 'Arab Muslim', or as 'Arab Americans'. Amaney Jamal noted that some Arabs endorsed their collective Arab American identity because of social and cultural factors and the political situations of their country of origin. Through various institutions - family, Arab and Islamic schools, social and cultural organisations and social networks - Arab Americans continue to reproduce their Arab identity characteristics in the US. ${ }^{34}$ Nadine Naber further noted that Arabs are a heterogeneous group; for example, there are Lebanese, Iraqis and Sudanese, but they are conflated by the media and Hollywood movies into one homogenous 'Arab' group. ${ }^{35}$ Other scholars have observed that Arab stereotypes in the media, such as 'backwards', 'murky oil sheikhs' and 'terrorists', could be a compelling reason to endorse a collective Arab American identity. ${ }^{36}$ (I discuss media stereotypes further in Chapter 4.) Steven Salaita wrote that the constant 'othering' of Arab Americans since 9/11 is reinforcing the tendency of the Arab population in America to endorse a unifying Arab American identity. ${ }^{37}$ As the social theorist Richard Jenkins said, 'Individuals, in using stereotypical categories to define themselves, thus bring into being human collective life. Individuals will self-categorise themselves differently and the contingencies with which they are faced. ${ }^{38}$ In the following subsections, I examine the construction of an Arab-Muslim, Arab American identity and how it is manifested.

\section{Arab to Muslim Arab: same social group}

Hameed, of Egyptian origin (male, 15, US born), identified himself as an 'Arab': 'I just like to classify myself as Arab 'cos the fact, it's like pointing out that I'm Egyptian; actually it causes [division], the other Arabs like Palestinians go against us and I think Arab in general is better' (interview, New York, November 2009).

Hameed attended an Islamic school where he felt if he retained his ethnic (Egyptian) identity he would be distinctive among his school friends, who were mostly Arabs of other nationalities. Hameed said that if he retained his Egyptian identity, the Palestinians may 'go against us'. It was not quite clear whether the Egyptian political situation had any impact on this statement. Egypt has long been an ally of Israel, so for that reason a few Egyptian students, who formed a minority in the school, may have felt marginalised and therefore decided it was necessary to adopt the broader 'Arab' identity. Hameed was fond of basketball and lived in a predominantly Arab area.

Safwan, of Palestinian background (male, 16, US born), attended the same Muslim school and said that he felt 'Muslim Arab'. Safwan was born in the USA but was raised in Palestine, where he spent ten years. He also went to Palestine 
every year with his family. He has seen the hardship of the Palestinians in Palestine, though he is from the peaceful part of Palestine, Ramallah. Safwan speaks fluent Arabic and listens to Arabic music. When I asked him if he had a girlfriend, Safwan replied, 'No, we don't ... it's harram.' I asked him, 'You listen to which music - is it hip-hop, rap?' Safwan replied, 'More of cultural music ... there's a lot but the one I mostly listen to, his name is Naser el Fares, he's also from Palestine, Ramallah.' Safwan later explained the kind of songs Naser el Fares sings. 'Ah well, it's more of like wedding songs, but it's the day before the wedding, we have this party for the men that they do at night ... he sings dabke falasteeny.' Dabke is the cultural Arab dance for wedding occasions and a dabke falasteeny is a specific Palestinian variant. Regarding his identity, Safwan said:

I feel I'm more of a Muslim Arab, yeah. I speak the language. I was born here and my parents are from there. Well, we feel that there is no difference; in the end we're all Arabs, it's the same thing, just different places that we live in. (Interview, New York, November 2009)

Instead of identifying exclusively as Palestinian, Safwan chose the broader Arab-Muslim identity, perhaps because it suited his ideology to 'fit in' with his school's broader social circle. Safwan enjoyed swimming and lived in a predominantly 'white mainstream American' suburb.

\section{Arab American: a lot of outside pressure}

Habib, of Libyan origin (male, 16, overseas born), was not into sport but he liked reading. Habib attended a public school. At home he spoke Arabic. I asked Habib, 'Your Libyan Arabic, is it similar to Palestinian Arabic or Iraqi Arabic?' He replied, 'Yeah, kind of. It's a little bit different, but it's still basically Arabic. We would understand each other.' Regarding his identity, Habib said:

I would say 'Arab American' because it's important that I'm from Libya but when you talk to other Americans you just say 'Arab American', because if you tell them 'Libyan' they're not going to like it ... They immediately relate you to Gaddafi. There's a lot of pressure. You have to think what you have to say before you say it. (Interview, Michigan, April 2010)

Habib spoke about the then Libyan leader, the controversial Colonel Muammar Gaddafi. 'Well, I personally, my family at least, we don't really support him, so what we think he is doing is wrong and the media talks about how it's wrong, we agree with them pretty much.' Habib also referred to the Lockerbie plane bomber Abdelbaset Ali Mohmet al-Megrahi's cancer diagnosis. Habib said, 
'They said that he had cancer or something, so they were going to let him out of jail.' It was interesting to note that a second-generation Libyan American youth was well informed about incidents related to Libya.

In January 2001, al-Megrahi was convicted of killing 270 people by blowing up Pan Am Flight 103 over Lockerbie in 1989. However, in August 2009 , he was freed from prison in Scotland on compassionate grounds because he was said to be suffering from terminal prostate cancer. Al-Megrahi returned to Libya but there was strong protest in some of the US media. During that period I was in the USA for my research on young American Muslims' identity. So I expected to find a situation of unease for people of Libyan/Arab background, even if they did not support such terrorism. Megrahi died on 20 May 2012, nearly three years after his release from prison.

\section{The question of loyalty}

Two participants, Bakr and Murtaza, volunteered to sit for an interview together and identified themselves as Arab Americans. Bakr, of Syrian background (male, 18, US born) said, 'I would say I'm an Arab American you know, I am half-half, like in blood too' (interview, Michigan, April 2010). Bakr has visited Syria several times with his parents, so his Americanness comes from the place where he was born and raised and his Arabness from his heritage. Murtaza's explanation was that his father has lived in the US for a long period and has endorsed both Arabian and American culture; so, like his father, he chose to identify himself as Arab American. Murtaza also said that Palestine was still an occupied territory, so there was no point for him to endorse an alternative Palestinian identity.

Both Bakr and Murtaza were keen on sport, which reflected their American identity. Bakr played basketball and he supported the local team, the Detroit Pistons, whereas Murtaza preferred American football and supported the Minnesota Vikings. But when it came to joining the army, their Arabness came to the surface. They spoke of the Arab American festival that takes place in Dearborn every year:

We just have it on the street. They just close it down from Greenfield to Schaffer and the whole street is just music and festivals and stuff. They bring in the rides and stuff and ... It's free and they have it in July. Yeah, it gets bigger and bigger every year.

They explained how the US Army and the CIA are keen to hire Arabs/Muslims at this event:

I think it was like the last two times the US Army and the CIA were there. They have business booths ... they want to hire translators. It's a bad thing because you are translating for countries that you are originally from, you know. It's kind of like a 
double [-crossing] thing ... And you are from the other countries so, just stay away from the army, just totally stay away from it, the whole thing.

Both Bakr and Murtaza were concerned that unemployment was very high in Michigan (about 15 per cent) and that it was difficult to find work. However, their Arab identity was preventing them from seeking employment in the US security forces. It should be noted that in 2010 the number of military personnel on active duty in the US armed forces was 1.46 million. ${ }^{39}$ Yet in the same year, there were only 3,500 Muslims in the US military which constituted a tiny minority $(0.24$ per cent) of the total active duty personnel in the US armed forces. ${ }^{40}$

\section{It is the media}

Finally, Amjad, of Jordanian background (male, 18, overseas born) said this about his identity:

With the people I am [with], I mean it [my identity] changes, it differs. I was raised here in America even though I was born in Jordan and at home I have an Arab identity of course. I still retain, you know, both Arab and American identity. (Interview, Massachusetts, November 2009)

To my question 'How do you connect yourself to your American identity?', Amjad replied:

Oh, sports-wise, for example, [a] competitive background that I feel that has been instilled in me being raised here. Education-wise ... as American culture, they are very competitive, they're very strict with their education, like everyone always seeks to be the best in their field and excel. I feel that has also been instilled in me living here. That, you know, you believe maybe not so much in what used to be called the 'American Dream' but more in that there's always an opportunity and just how you see it; it all depends on how you see it.

Amjad's American identity was reflected in his sports and education. Amjad's Arab identity appeared when he was critical of the media.

I don't feel the media is really impartial when portraying Muslims . . . for example, Tareq Mehanna, the person who was arrested from Worcester [Massachusetts], he taught in Worcester and I believe he lived in the Boston area ... The media focused more on what he was alleged of doing, and they really didn't focus on the qualities of the person himself . . . I mean it was one isolated incident but then by displaying it nationally the whole world started ... they view one person, they exercise that view upon the group, that's all. 
Amjad meant that the media can sometimes portray a Muslim so negatively that the whole world comes to view all Muslims negatively. In 2008, Tarek Mehanna, an American-born Muslim of Egyptian background, graduated from the Massachusetts College of Pharmacy, where his father was a professor. In October 2009 Mehanna was arrested in Sudbury, Massachusetts on charges that he was planning a 'violent jihad' against US politicians and American troops in Iraq and conspired to shoot randomly in shopping malls. $\mathrm{He}$ is alleged to have conspired with two other men. However, some Muslims felt that Mehanna was innocent and that the government was trying to foment Islamophobia. ${ }^{41}$

\section{Single ethnic identity}

Stuart Hall observed that identity is fluid and is subject to change under different circumstances. It is produced through specific historical and institutional structures. However, it can also emerge within the play of specific modalities of power, and thus is more a product of the marking of difference and exclusion. Sometimes it can be a sign of unity (without internal differentiation) versus the external 'other' ${ }^{42}$ Social identity theory indicates that sometimes differential treatment by the majority group may lead to an 'outgroup' sentiment, which may impact on one's identity formation..$^{43}$ Also, immigrants living in diasporas may desire one day to return 'home' and therefore they remain strongly connected to their ethnic culture.

\section{I'm only Guyanese}

Qutb (male, 18, US born, Guyanese background) identified himself as 'only Guyanese'. He was born in the USA and had never been to Guyana but said, 'Yeah, my parents are Guyanese so I would consider myself Guyanese . . . 100 per cent.' I asked him, 'Do you socialise more with the Guyanese community?' Qutb replied, 'Not really, I socialise with a very diverse type of people in New York and through high school, but my connection is through family.' On his leisure time activities, Qutb said, 'As a child, no I haven't played much sport ... Leisure time is mostly with computers' (interview, New York, January 2010).

In the Australian context, in 2004, Elsa Germain conducted research on 400 young people of minority cultures, aged twelve to nineteen. The participants were of indigenous or non-English-speaking backgrounds. Germain found that the participants who had lighter skins or looked white would identify themselves with the Anglo-Australian identity and describe themselves as 'white', whereas the visibly ethnic participants would adopt a bicultural identity rather than their exclusive cultural identity. However, some visibly ethnic youths, such as the Torres Strait Islander respondents, felt they did not 
'belong' and were more likely to acknowledge their cultural roots because that appeared natural. ${ }^{44}$ Similarly, Qutb chose to link his identity with his family, so it manifested itself through his choice. However, the next two case studies are of participants whose identity was constructed through the 'othering' of the wider society.

\section{I'm a Bangladeshi, 100 per cent}

Maimuna (female, 30, overseas born, Bangladeshi background, educator) identified herself as 'Bangladeshi 100 per cent'. Maimuna migrated to the USA in 2007, so she still felt very connected to her country of origin. Also, Maimuna was upset about her perceived 'outgroup' treatment. She said:

I just want to share with you one of my bad experiences in [the] time of my citizenship interview. I went to the immigration office and I was wearing my hijab. The lady immigration officer asked me some questions and she also interviewed my husband but I think it's not normal [questions]. My husband has [a] beard and [the] first question was if we were married. After that she asked me two more questions: 'Are you involved in [any] terrorist group and do you donate to a Muslim terrorist group?' This is humiliating or this is racism, whatever you say, I think so. And the other question: 'Do you hate any group?' She specifically asked me, 'Do you hate Jewish people?' I said, 'No. Why should I hate the Jewish people? I came here from Bangladesh and, do you know, we are new here, we are struggling to establish ourselves, we have no time to hate any people. We are struggling in language or culture, everything. We have to adjust ourselves with this culture.' It was so embarrassing. (Interview, Michigan, April 2010)

The question 'Are you involved with a terrorist organisation?' is written on the immigration form which everyone coming to the USA or Australia has to fill out. For security reasons, this question is necessary, though Maimuna thought that she and her husband were asked this question because they were visibly Muslim. However, the question asking if Maimuna (and her husband) hated Jewish people was subjective. A Muslim appearance (for example, the hijab) can have an impact on some people. In this context, I would like to share my mother's experience at an immigration/customs office in the USA. She was travelling with me from Bangladesh to the USA. She looked Muslim. She was wearing a sari and a scarf over her head. At the airport immigration counter (for incoming passengers) we were asked to go to the immigration office, which was also located at the airport. My mother and a non-Muslim black woman passenger were waiting in their wheelchairs for the immigration/custom officers to call them (for visa reasons). They kept my mother waiting for more than an hour and let the other woman leave within a short time. I was surprised that while both women were wheelchair (special assistance) passengers, my mother 
was treated differently. It was also offputting when the immigration officer asked me if I spoke English, though I did not look visibly Muslim (I did not wear any conspicuous Islamic dress). They simply associated me as the 'other' because I was with my mother.

A certain topic was a common concern for some participants, though their national identities differed. For example, Maimuna expressed concern over the new immigration laws passed in Arizona:

Now [the] immigrant issue in Arizona is a burning question. I mean President Obama attracts the young generation, he has magnetic power, just everybody [is] focused on how Obama is doing good. Sometimes I think people forget to judge if he is doing good or bad. I think after ten years or twenty years history will tell whatever he did good or bad, not now.

Maimuna did not explain Arizona's new immigration law, but she questioned whether President Obama had any say over it. Bushra, another participant (female, 18, overseas born), explained the law. She mentioned her identity as 'Bangladeshi Muslim American', yet like Maimuna she was also concerned about the law:

The governor passed - I'm not sure who the governor is, but she passed the immigration laws in Arizona, which means that they're going to try to limit the number of immigrants in their state, within their borders. And the cops, the authority, the police are now allowed to pull over anyone who's suspected of being an immigrant. And at all times Arizona residents or anyone visiting in the state of Arizona must carry paperwork, legal paperwork, such as a passport and a birth certificate to prove that they are American residents. And, if not, they can be jailed up to six months. (Interview, Michigan, May 2010)

On 23 April 2010, Arizona Governor Jan Brewer signed into law what many call the toughest bill on illegal immigration in the country. The bill makes it a crime to stay in Arizona illegally, requires all aliens to carry immigration paperwork, and levies sanctions against employers who knowingly hire illegal workers. Facing criticism that the law would legalise racial profiling, the Arizona legislature modified the law on 1 May 2010. It now states that police officers cannot use race as the sole grounds for suspecting that someone is in the country illegally. On 27 May, the talk radio host Glenn Beck said on his show that ' 64 per cent of Americans support the Arizona immigration law'. And a Pew Research Center poll conducted between 6 and 9 May 2010 found that 59 per cent approved the law. ${ }^{45}$

Though the immigration law in Arizona may impact on Hispanics, Muslim leaders observe that it will also impact on Muslims. A Muslim leader in Michigan, Dawud Walid, said, 'Since legal status in America cannot be 


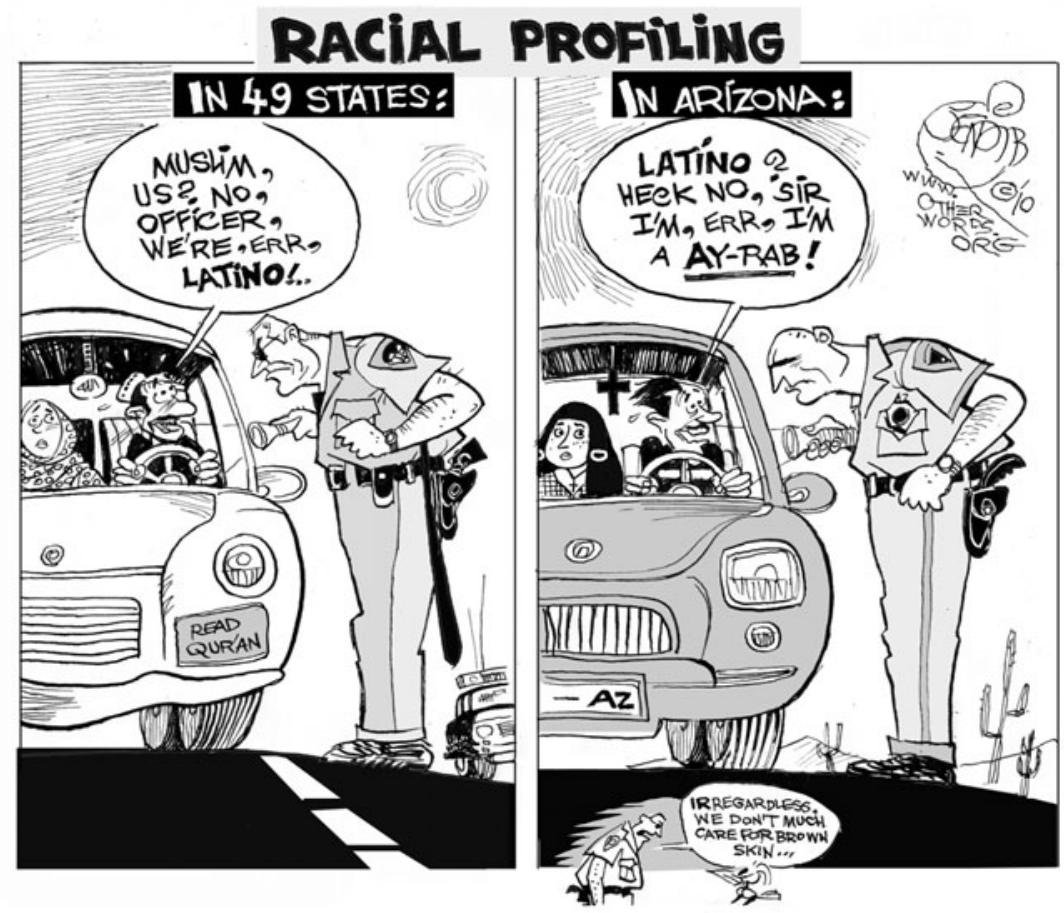

Figure 3.1 Racial profiling. From Muslim Observer, 6 May 2010 (C) Khalil Bendib, all rights reserved.

ascertained by looking at persons' skin colour or religious attire, this bill becoming law has the potential of targeting Latinos and Muslims from various national backgrounds' ${ }^{46}$ (see Figure 3.1). President Obama was also critical of the Arizona law when he said that it threatened 'to undermine basic notions of fairness that we cherish as Americans, as well as the trust between police and our communities that is so crucial to keeping us safe'. ${ }^{47}$ However, this law was passed by the Arizona state senate, so President Obama could not overhaul it.

\section{Why I am a Somali}

An overseas-born participant of Somali origin, Zaker (male, 24, educator), migrated to the USA at the age of four, where he was raised and educated, but when asked he said, 'I am a Somali.' Zaker was very passionate about American sports but at the same time he felt very connected to his country of origin, even though he has never visited Somalia since migrating to the United States. Zaker said, 'We have a region called XXX, that's where my tribe lives. And it's a very interesting place where actually now they say there is more 
genocide than Darfur.' Like many immigrants, Zaker was concerned about the ordeals of his people back home. Zaker showed me his key ring, which had an emblem of his clan on it, and said, 'You can see my key tag, and on 21 September we have this thing called, like, World Peace thing.' Zaker added, 'Yeah, World Peace Protest, and then that day I want to actually have all these people come out. Like learned people, people like you who don't know what XXX [my tribe, its people and their ordeal] is all about.'

Zaker criticised the US media for profiling the Somali people as 'pirates' and was critical of the American government's handling of the case of a fifteen-year-old Somali pirate, Abduwali Abdukhadir Muse. Zaker said that in Somalia normally the pirates send 'a guy to deliver a message'. In this case they sent Muse to a US ship on the Somali coast, and he was captured and sent to the US for trial. Zaker observed:

However, that fifteen-year-old, I believe personally, should have gone to court in Somalia, should receive his punishment in Somalia, you know, because he's a Somali citizen. You cannot bring an American boy to Somalia and say, 'We're going to put you in court.' If America has free speech, freedom of anything, I am willing to say that was wrong, you know? What I believe about pirates is they're little boys, fifteen-year-olds, seventeen-year-olds, uneducated, that are trying to find food. Why they're doing that is because that's the way to bring money home. (Interview, Massachusetts, November 2009)

It was reported that on 8 May 2009, Muse led a gang of four pirates who attacked an American ship, the Maersk Alabama, demanded a ransom of $\$ 2$ million, and took the captain hostage. Muse was wrestled down, tied up with a wire, and later brought to the USA for trial. The three other pirates involved in this attack were killed by Navy Seal snipers in a rescue mission for Captain Richard Philips of the Maersk Alabama. However, New York civil rights lawyers have questioned the legality of Muse's being in American custody rather than Kenyan, which has an international agreement to prosecute terrorists, and whether his prosecution was lawful given the uncertainties surrounding his age..$^{48}$ In May 2010 Muse was convicted of the hijacking of the Maersk Alabama and the kidnapping of its captain. He was sentenced to nearly thirty-four years in prison. ${ }^{49}$

As Zaker continued his interview, he said that he had been a victim of racial profiling by the FBI at a time when he was representing the USA as an elite national icon in another western country:

My mother called me crying, tears and like, 'Where are you, what are you doing, are you up to no good?' . . . And they're [the FBI] in my home harassing, and my mom lost 18 pounds 'cos she was worried. They asked her, 'Where is your son? What does he do? Do you know anything about him?' He [the agent/investigator] never came 
out with anything ... I got a lawyer and then my lawyer had to call him and clear that up but there was nothing to clear. Like why you're harassing this guy - because he's a Somali, because he's a young Muslim? How many Americans that are not black, not Muslims are there doing things?

On the topic of the USA Patriot Act, Zaker spoke of his ordeal when he was at a US airport:

Until this search and FBI and all this ... I'm still shocked, you know? I'm a young, educated African American man, who never thought about nothing but good about life now. But when I see all these searches, all these discriminations, breaking your privacy, you know, not having human rights, basically I don't have any privacy. I think I lost rights, my human rights were violated here in America, where the man [at the airport/border security] was telling me that you've got to tell me how much money you make. I can't refuse to answer because he's going to have me there another eight, ten hours, you know? He takes my cell phone and keeps it like five, six hours; he gets my laptop; he gets my videos; he takes basically my wallet...

Speaking about ... missing flights, there were times that I missed flights and I had to spend the night over at the airport, wait until the next day because of searching.

As revealed through his interview, Zaker felt connected to his country of origin, Somalia. Zaker's connection to his Somali community was revealed through his social work with young Somalis and, finally, his dream was that Somalia would get US approval and that one day he would visit Somalia. While speaking of racial profiling, Zaker speculated that he was victimised because he was 'black', 'African American' and 'Muslim'.

Sometimes US security officials can go overboard with their searching of the visible 'other', but it must be acknowledged that some Somali Muslims have become a security concern. For example, it was a matter of great concern for the Somali Muslim community and the wider American society when in 2008 some young Somali Americans from Minnesota went to Somalia to join the jihadi al-Shabaab group led by Ahmed Abdi Godane. It is alleged that al-Shabaab had alliances to Anwar Alwaqi's al-Qaeda in Yemen and to the Pakistani-based al-Qaeda terrorist network, that it had up to 3,000 fighters and a batch of American recruits. And al-Shabaab had been branded a terrorist organisation. In 2008, a 26-year-old first-generation Somali American from Minnesota, who had been trained by al-Shabaab, carried out a suicide bombing against the Somali government. And in 2009 Burhan Hassan, a seventeen-year-old Somali American also from Minnesota, went to fight with al-Shabaab and was killed in Somalia. ${ }^{50}$

I believe that security is important but when it takes the form of stereotypes, it is not helpful. For example, in his interview Zakir also said that sometimes 
at US airports, he was asked which tribe he belonged to, and at times in his neighbourhood, people yelled 'Pirate!' at him.

\section{Religious identity}

\section{Only Muslim identity}

Some female participants in this study said that they did not have any alternative but to assume an Islamic identity because that is what their parents wanted by sending them to Islamic schools or youth clubs. Some said that they assumed an Islamic identity because of peer pressure; for example, in a public school or university if they did not wear the hijab then their Muslim friends who wore the hijab would view them as the 'other'. ${ }^{51}$ Others have chosen a Muslim identity of their own accord; for example, Afrosa (female, 15, US born, Bangladeshi background) said, 'I feel more Muslim because American people, they do different sort of things. Muslims follow everything their parents say and the Quran, that's what I follow' (interview, Michigan, April 2010). ${ }^{52}$

In the British context, however, Avtar Brah observed that sometimes the discourses and practices of Islamophobia can lead Muslims to specific religious identification and connect them to the Muslim ummah nationally and transnationally. Furthermore, conflicts in global sites such as Iraq, Chechnya and Kashmir increase their sense of grievance on behalf of all Muslims. ${ }^{53}$ In my study, I found that some participants' connection to a Muslim identity was through either ethnic or religious ingroup feelings (discussed next).

\section{'I'm Muslim'}

Shimaz (female, 15, US born, Pakistani origin) said, 'I'm Muslim, not Pakistani, and not American.' Shimaz was struggling with her ethnic identity because she was not brought up in her parents' country of origin. She felt comfortable with her Muslim identity because she spent her time in an Islamic environment and attended an Islamic school. Shimaz said that she watched American football with her brothers on the TV, and that she was a fan of the Pittsburgh Steelers. However, she did not connect herself with an American identity because she observed that mainstream society, particularly the media, was treating Muslims as the 'other'. She expressed this dilemma as she spoke about the controversial Afia Siddiqui case:

Afia Siddiqui actually was in Boston, she was a doctor there. And you know, they [the media] twisted her story around because she went to Pakistan to visit her mom with her children and when she was in a cab to go back home, her car was stopped and she had no idea why she was being stopped or anything. They took her children away from her and they separated her away from her family ... and the media put 
her in some mental place. And they changed the story around over and over again, but apparently she is guilty of holding a gun [to] a CIA agent ... They [the media] want to give Muslims a bad name and they just feel so negative about us. (Interview, Maryland, February 2010)

The Guardian reported that Afia Siddiqui disappeared from Karachi in 2003 and reappeared in Ghazni, Afghanistan in 2008. It was alleged that there was a dispute in a police station in Afghanistan and the US accused Siddiqui of trying to shoot two soldiers and two FBI agents. She was sent to the US in 2009, tried and in 2010 sentenced to eighty-six years in jail. ${ }^{54}$ Consequently, in Pakistan Siddiqui became a cause célèbre. Critics and supporters in Pakistan compared her case with that of the FBI contractor Raymond Davis. Despite allegedly killing three Pakistani citizens, Davis was set free to return to the US in January 2011. ${ }^{55}$ In April 2011 Raza Rabbani, a senator for Sindh in the Pakistani parliament, commented in a US report about the following US major violations of human rights: the Siddiqui case; killing people in drone attacks; using power in Iraq and Afghanistan; and the inhuman manhandling of prisoners, which continues at the Guantánamo camp (despite corrective measures announced by President Obama). ${ }^{56}$ Both the cases (Siddiqui and Davis) are complex, but the point I would like to make is that incidents that connect to ingroup identity can play a major role in people's identity formation. Especially noteworthy is that in this study only some participants of Pakistani origin discussed the Siddiqui case, which again shows their ingroup ethnic (Pakistani) connection.

\section{I'm Muslim, 'Slave of Allab'}

Faizul (male, 24, overseas born, Bangladeshi background) migrated to America with his parents when he was eight years old. He attended a public school with other students of diverse backgrounds. He eventually became an educator and was involved with Islamic organisations. Regarding his early life, Faizul said that he stopped lying and stopped hanging around with the wrong friends. $\mathrm{He}$ confessed, 'I used to work in a bar, and I needed to get away from all those bad things. So I became a better individual, morally and ethically.' On his entertainment choice, Faizul said that he listened to music 'but the clear clean ones'. In sport, Faizul likes ice hockey: 'I like [the Detroit] Red Wings a lot and I only watch them; other than that I try to keep away because it's very addictive ... They lost 2-0 for now but we'll come back, insh'Allah.' Faizul defined himself as a Muslim, and provided several reasons for his exclusive Muslim identity. First, he related himself with religion:

I consider myself a slave of Allah, working for Allah towards any human being ... if there's an accident outside my road, or outside right now in the building, I'm not 
going to sit here and identify this individual as Christian or Jew, I'm going to identify them as human and that is why Allah has sent Prophet Muhammad [PBUH] to serve the humanity. (Interview, Michigan, May 2010)

Then he expressed his ideological battle with the American system: the American media, the FBI, American foreign policy and American democracy:

If my ideologies or my beliefs come in contradiction of what American ideologies are, I'm sorry, I'm going to take my belief before my culture. American media is always negative on Muslims. For example, whenever they're allowed they would make fun of prophets and messengers but whenever you make a comment about Israel they're really mad and they're really scared... CNN an example, Fox too.

Further on the media, Faizul said, 'For example, look at what's going on at Guantánamo. There are so many tortures and oppression but none of it the media showed, nobody revealed it.' Faizul thought the American media did not provide accurate international news, saying, 'Look what happened in Iraq, in Afghanistan. They always hide things, they always do undercover things. Why should I believe what they tell me about [the] Fort Hood shooting [see Chapter 4]?' Then Faizul spoke of an FBI raid on some Christian militia in March 2010 and compared it with the heavy-handedness of the FBI in the Imam Luqman case: 'Well, hello! What happened to Iman Luqman? How come you guys [FBI] shot him down? Nineteen times, yes. It doesn't make sense. Logically, it doesn't make sense. ${ }^{57}$

The question of the FBI's shooting of the African American Imam Luqman was also raised by other participants who lived in Michigan. In October 2009, Imam Luqman Ameen Abdullah was shot a total of twenty times (incurring twenty-one wounds, from which he died) during a raid by federal law enforcement agents on a warehouse in Dearborn. The autopsy on Imam Luqman found that he was hit twice in the chest, four times in the abdomen, twice in the groin, four times in the left hip and side, seven times in the left thigh, once in the scrotum and once in the back. A federal indictment alleged that Imam Luqman led a radical separatist mosque and a stolen-goods ring, and that he had opened fire during their raid on a stolen-goods operation. However, Dawud Walid, executive director of CAIR Michigan, questioned why, if Imam Luqman had been killed instantly, he was found handcuffed. ${ }^{58}$

Faizul also expressed his Islamic identity through other points:

I didn't vote. My parents voted; I didn't vote and I don't want to support the system in any way. Because I believe for me to even support such a system that does not give any kind of fairness, like I said, there's no free education, there's no free health care system. It's not providing me anything and I don't believe in democracy because it's against my belief. Islam says sovereignty belongs to God, it doesn't belong to 
humanity ... So if American ideology contradicts this, if people cannot see clearly that it is doing wrong to humanity, then I don't know what I can put my emphasis on.

Faizul was not only critical of US domestic and foreign policies; he was critical of Muslims living overseas who failed to work for their fellow Muslims. When I asked him if he had watched a recent Bollywood movie, My Name Is Khan (which was critical of the US government's racial profiling after 9/11), Faizul replied, 'I'm kind of against certain movies, such as My Name Is Khan.' Faizul explained his distaste for the movie: 'Personally I think Shahrukh Khan [the lead actor in My Name is Khan], who is very famous out there, could do a lot for Muslims but I don't think he's doing enough.' Once again Faizul linked his Islamic identity transnationally when he said:

Shahrukh Khan is not doing enough for the Muslims because if he was to, at least he should have stood up for the Gujarati Muslims at that time when they were getting slaughtered in 2002. I don't think he was doing anything about it.

Faizul was referring to a conflict between Hindus and Muslims in India. On 27 February 2002 a train bound for Ahmedabad, the largest city in Gujarat, was set on fire and fifty-eight passengers, including twenty-six women and twelve children, were burnt to death. It is alleged that kar sevaks (Hindu volunteers) had harassed Muslims travelling on the train and provoked them to carry out this heinous crime. This tragedy led to violence in Gujarat: from 28 February to 2 March 2002, sixteen of Gujarat's twenty-four districts suffered organised armed mob attacks, in which 2,000 lives were lost, 270 mosques and religious and cultural monuments were destroyed, and the Muslim community of Gujarat suffered an enormous loss worth 35 billion Indian rupees. ${ }^{59}$ Faizul concluded by praising the journalist Yvonne Ridley:

Look at her experience with the Taliban. What is her response? Yvonne Ridley, the British news reporter, when she went to Afghanistan, she got caught by the Taliban [on 28 September 2001]. In [the] ten days they were holding on [to] her, and in [those] ten days [with] the treatment they give her, she came back and became Muslim. She said, 'I couldn't believe these people treated me so right, they wanted me to eat, they locked me up in a room, they gave me the keys to the room and they said, "This is your room." 'She was shocked by the [considerate] way they treated her, you know. ${ }^{60}$

\section{'Americanness'}

When I asked the African American participant Ehsan 'What is it to be an American?' he replied, 'To be an American, first, I guess you would have 
to love this country. It's like [you would] follow the traditions of America - sports on Sundays, apple pie, baseball, national pastimes ... Yeah, like baseball' (interview, Michigan, May 2010). Some participants in this study identified their Americanness in other ways.

\section{Two different worlds}

Haneef, of Pakistani background (male, 17, overseas born), migrated to the USA in 2001. He spoke Urdu, and was fond of multicultural food: '[I like] Pak food ... but my mom likes to cook English foods; she cooks Italian food, and watches the Food Network.' Haneef had restrictions at home on watching television: 'At home my dad allows no TV because nobody does their homework, and then when he calls for something they don't go and listen so they just keep watching TV, so that's why he said it affects the education.' On his identity, Haneef said, 'I will say American 100 per cent,' giving the following reasons for his connection to the USA:

Because everything is over here, education is much better than over there. They [Pakistani education system] give you a lot of work. Here teachers are very nice, they're very polite to you and ... [In Pakistan] it's more congested, that's what I say ... more pollution. (Interview, New York, November 2009)

Haneef attended a public school in New York and worked part time in a fast food shop. When I asked if there was a mosque in his neighbourhood, Haneef replied, 'No, I don't go to any mosque.' Regarding sport, Haneef said, 'I play handball with my friends. Sometimes I watch [the] Super Bowl. I support the New York Giants.' Haneef spoke of the walk that he did to raise money for cancer research: 'They [the Pakistanis/Muslims] should try to help as this is, like, their country. I never feel I'm a foreigner. I never feel different, so they should try to help this country to take it up, rise it up [sic].' Haneef added, 'I'm going to do engineering to help this country out. Yeah, it's an open country.'

Haneef chose his identity as American perhaps because he felt connected to the wider society through his part-time work and his voluntary work (the cancer walk), he felt more integrated with the wider community through his public school, and because he appreciated the American education system and sport.

\section{No discrimination}

Other reasons given by participants who felt very American (though some of them were visibly Muslim, for example bearded men in long Arabic attire, or women wearing hijabs) were: 
- They were born in the US.

- They had been living in the US for a long time.

- They were fluent in English.

- They worked in mainstream American shops and other businesses.

- They had an American girl/boyfriend.

Faiq, of Somali background (male, 17, overseas born), attended an Islamic school in Florida but felt very American because he migrated with his parents at a very early age and had never been to Somalia. He sometimes went to Minnesota, where there is a large Somali community, but he only stayed there for a couple of weeks, so that did not impact on his identity. Faiq worked in a fast food store with mainstream Americans. He spoke about basketball, mentioning the names of some players he was fond of, such as the NBA player Kevin Durant. Faiq said that as a Muslim he never felt discriminated against:

I just speak English. So unless they know my first name, they can't tell I'm Muslim. And no one discriminates me because I'm Muslim, thank God. I don't get any of that. Neither does my brother. It's a little harder for my sisters, because they're hijabis. And when they go out they sometimes get looks. And it's uncalled for. They don't do anything. They get dirty looks and they're girls and they're sensitive. So I just tell them 'Don't let them bother you'. (Interview, Florida, March 2010)

\section{It's an open society}

Nawaz, of Yemeni background (male, 19, US born), said, 'I'm straight American. I'm an American citizen. I feel connected to America, 100 per cent.' Nawaz said that his grandfather and father had lived in the US most of their lives. However, Nawaz was concerned that his father would arrange a marriage for him, so he secretly became engaged to a Colombian Muslim girl (which his parents would not approve of). Nawaz said, 'If I go back to Yemen, I'm for sure getting married [to a Yemeni girl], but I don't want to go back though' (interview, Michigan, April 2010). Nawaz was keen on sport, including soccer, basketball and American football. In my research on young British Muslim identity, I found some Muslims disapproved of their children getting married outside their clan, and considered that having friends of the opposite sex was harram. It seems that Nawaz constructed his Americanness through his historical connections and having a girlfriend in the 'open and free' American society. ${ }^{61}$ In having to contend with two cultures, Nawaz preferred his Americanness. 


\section{It's my culture}

Parvez, of Pakistani American origin (male, 24, US born), said:

I realised how American I was when I travelled ... I'm attached to this particular part of America, I guess as my homeland. I went to Saudi Arabia last year [for teaching] and really I felt like, oh, you know what, I really missed my home because three months away from home is the longest I've ever been and I missed the American holidays. You know, fall for us is apples and pumpkins and Thanksgiving and Halloween, Christmas and like, over there, none of that. It gets a little bit cooler but it's not the same, you know. (Interview, Massachusetts, November 2009.)

Parvez's mother was a mainstream white American and his maternal grandparents (with whom he was closely connected) were non-Muslims. So he enjoyed the American cultural celebrations such as Halloween and Christmas, which are forbidden in Saudi Arabia. Parvez was not interested in sport but he enjoyed music and he was passionate about learning languages. He said, 'I love international music. There's this one Arabic musician, Algerian, Cheb Khaled. I like his music a lot. I love Brazilian music, rock music.' He was very transnational in his love for music. Parvez also took pride in performing the hajj while he was in Saudi Arabia. However, his identity construction was mainly influenced by American culture.

\section{No choice but to be American}

Aimal, of Lebanese-Greek origin (female, 17, US born) said, 'I play tennis, volleyball, I used to surf but I don't do that any more. I wrestle. I work out every day. I go to the gym. I just probably say I'm American.' When I commented 'I see you are wearing the scarf (hijab)', Aimal responded:

I started wearing one this year. I am new to Arabs. I've never been around Arabs my whole life. Honestly, when I first moved to this school, I was scared, because my cousin died in September 11, and I had it in my head that Arabs were terrorists. That's what I had the vision of when you hear so many things from different Americans. I came here and my dad was like, 'I want you guys near your culture, near your people. In this school you are going to have to start putting on the scarf.' I mean, I got really mad, I didn't want to put it on. I didn't want to be around different Arabs, because in my head Arabs were not a good thing. Especially because my relative got killed on the airplane on September 11, you know. (Interview, Michigan, May 2010)

Aimal feared that she would be viewed as the 'other' if she looked Muslim. She was forcing herself to be 'American' by being invisible through her western clothing. It is important to note that at least 358 Muslims died in the World 
Trade Center attacks, ${ }^{62}$ but the irony is that sometimes the wider society (particularly some media) failed to emphasise that Muslims were also victims of the terrorist acts of the jihadis (who can be lethal but constitute a tiny minority of the 1.5 billion Muslim population worldwide).

\section{To be American is my choice}

In contrast to Aimal, Daniel, of Palestinian origin (male, 19, US born), felt that it was important to be American and at the same time to express one's Islamic culture. Daniel (also a sports fan) said that he felt American at a cultural level:

Culturally speaking, on a more superficial level, I'm an American simply because that's where my sense of humour, my interest in clothing, stuff like that is American. Although I do obviously enjoy foreign cultures, but if I was to identify myself culturally it'd be American. (Interview, Florida, March 2010)

When I told Daniel 'But you are wearing Arab dress', Daniel replied, 'I wear it occasionally simply because I like to establish among the college population there are people wearing this [who] can still be people who speak English fine, who you can interact [with] and have normal interactions.'

\section{Sport and identity}

So far in this chapter, while discussing the identity of the participants, I have argued that the issues that are important to young American Muslims range from voluntary embracing of their identity through heritage and social groups, to various internal and external factors impacting on their identities. I have also examined their other interests (apart from their studies or work), and found that sport has impacted profoundly on the construction of their identity.

Andrew Parker and John Harris argued that identity is generated both internally (within ourselves) and externally (through our social involvement with other people), and sport demonstrates how people see themselves as well as how others view them. Therefore, sport can be a very important source for the construction and display of identity. ${ }^{63}$ For example, a person who follows suburban baseball may identify more with the wider white community than a person who is interested in basketball since the latter is more associated with an inner city (black) culture. Speaking of the importance of sport, Tony Schirato observed that when young people participate in organised sports such as soccer, netball, athletics, cricket and baseball, or in games without codified rules such as touch rugby or kickball, 'they are being subjected at some level to a form of socio-cultural training (learning to win, to compete to struggle and overcome)'. ${ }^{64}$ Sport also empowers them and raises their self-esteem, helping 
them to overcome various forms of tension such as racism, and ethnic- and class-based prejudice, as well as cultural restrictions.

In the British context, Parker and Samaya Farooq found that British-born Pakistani males in a Muslim school, aged fourteen to nineteen, negotiated their identities at different levels: internally, they wanted to be better Muslims by practising Islam, offering prayers, reciting the Quran etc., but on an external level they valued self-esteem (through exercise in school), the rational self (through following the Hadith); the disciplined self (through adhering to the rules of sports) and the united self (through the unity and cohesion of playing sport). The students had six hours of physical education per week, with an emphasis on team sports such as hockey, basketball, soccer and cricket. ${ }^{65}$ To sum up, Farooq and Parker argued that 'physical activity provided a social environment in and through which the production of the ideal "self" could be achieved'. ${ }^{66}$ In other words, through sport, young Muslims can negotiate their identity and in times of crisis can maintain their sanity.

Furthermore, young people who encounter everyday racism, or cultural restrictions, may find sport an antidote for their anxiety. For example, in my previous research on young British Muslim identity, ${ }^{67} \mathrm{I}$ found many participants were fond of Manchester United, and their favourite player was Cristiano Ronaldo (who played for Manchester United from 2003 until 2009 and since then has played for Real Madrid). So in the midst of politicians' debates on Muslim women wearing the niqab, and support for certain parts of shariah law, many young Muslims were embroiled in the world of sport. So in this study, I also questioned the participants on their interest in sport. Their responses were varied (see Table 3.2).

\section{Analysis}

Table 3.2 shows that out of 379 participants, 259 (68 per cent) watch sport. Out of a total of 167 male participants, 142 (85 per cent) watched sport, and out of 212 female participants 117 (55 per cent) watched sport. And many of the participants who watched sport also played sport, particularly basketball. Out of 259 participants (both male and female), 165 participants (64 per cent) watched basketball or American football. That is, 91 participants ( 35 per cent) watched basketball and 74 participants ( 29 per cent) watched American football. Fortyeight participants (18 per cent) watched soccer, 18 participants ( 7 per cent) watched baseball and 28 participants ( 11 per cent) watched other sports.

It is interesting to note that some of the participants who played sport did not watch it - probably because sports like volleyball, handball, kickball, table tennis, badminton, bowling, swimming, gymnastics, golf and cricket were not regularly shown on American TV. For example, Omran said, 'I have a black belt [in the] traditional kung fu of Indonesia. I play soccer, I play badminton and of course I do jogging' (male, 16, US born, of Sudanese origin, national 
identity: Muslim American, interview, Florida, February 2010). Some participants enjoyed watching or playing sports that are more popular in their country of origin:

- Riaz (male, 20, US born of Guyanese background, national identity: Guyanese American): 'In Guyana it is mostly played cricket, so I watch cricket.'

- Aysegül (female, 15, US born of Turkish origin, national identity: Turkish): 'I support the Turkish soccer team.'

- Erphan (male, 19, overseas born of Iraqi origin, national identity: Iraqi American): 'Soccer ... My father was a soccer player.'

- Sadat (male, 18, US born of Palestinian background, national identity: Palestinian): 'After work I like to go out with my cousins and play cards.'

In some cases, young participants showed their loyalty to their local teams; for example, Ata (male, 16, national identity: African American), said, 'Like sports and everything? Yeah. Basketball: my favourite is the LA Lakers. But being I'm from Detroit, the Detroit Pistons' (interview, Michigan, May 2010). Anis (male, 16, Pakistani origin, national identity: more American) said, 'I support my local team, Ravens from Baltimore; I am a fan of Ray Lewis, Ravens, football' (interview, Maryland, January 2010). It is interesting to note that, though the participants identified themselves in various ways, when they affiliated themselves with sport they appeared to be very American; for example, Nazneen (female, 18, US born, Afghan origin, national identity: 'I consider myself an Afghan'), said:

I watch hockey, I love the big [Washington] Capitals. They were in Pittsburgh ... Like the thing is, Capitals and the Pittsburgh Penguins, they were like big time rivals and we won.

Ever since I was young ... my dad would just watch it and I'm pretty sure it was 1996 or 1998 when they first went to the play-offs and they were so close to winning the Stanley Cup, which is like the big cup. And they lost, I'm pretty sure, to the Pittsburgh Penguins, and ever since then they were just big time rivals. (Interview, Virginia, January 2010)

Anwara (female, 15, US born, Pakistani origin) identified herself as Muslim: 'I'd say I'm 100 per cent Muslim 'cos I wouldn't want my culture or anything to mix in with my Islam and my religion.' However, when the discussion of sport came up she said, 'I love to watch basketball, soccer and baseball' (interview, New York, January 2010). Some female participants said that they became fond of sport because their family members, father or brother (and in a few cases husband) watched and they joined them in watching sport. Another participant, Rabab (female, Ivory Coast origin, national identity: 'Muslim first, 


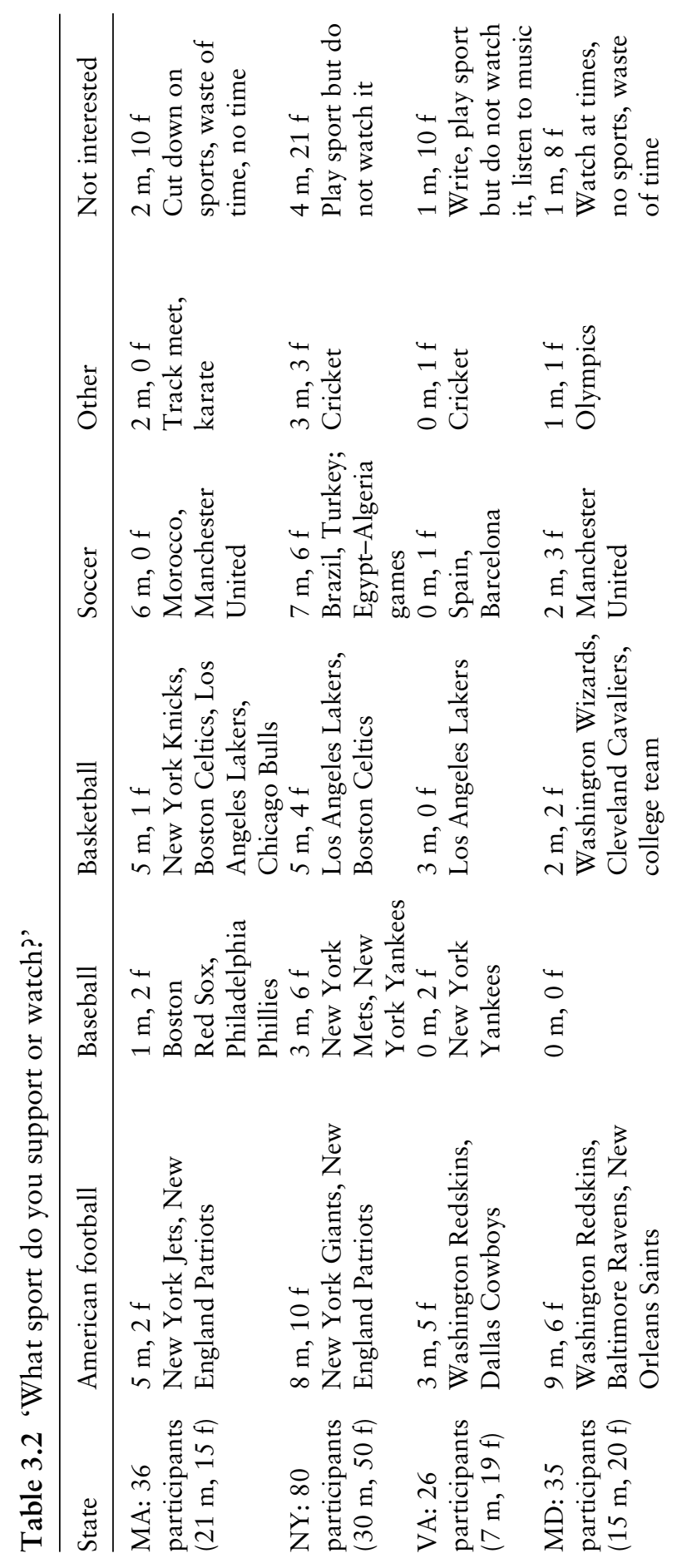




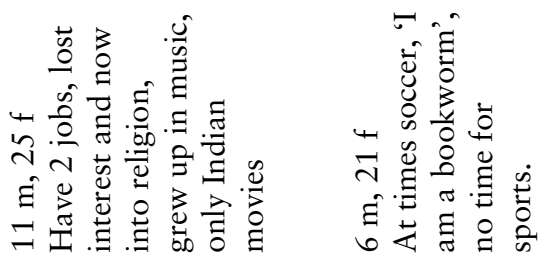

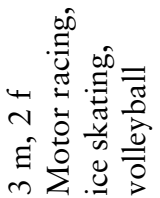

$+\frac{\pi}{\underbrace{\frac{\pi}{3}}}$

Eี

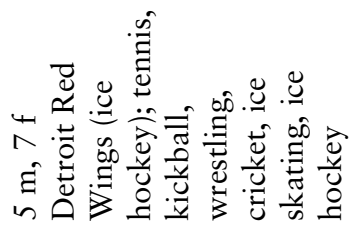

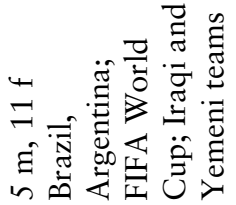

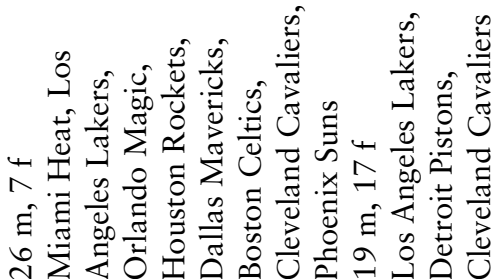

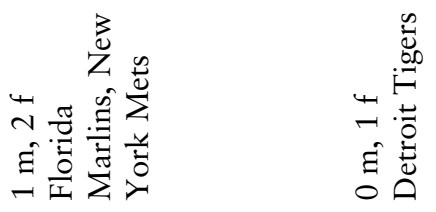

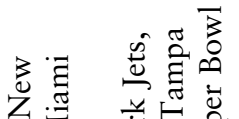

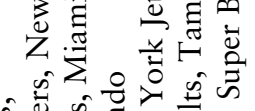

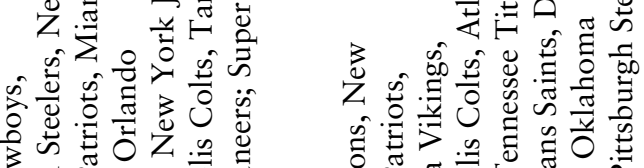

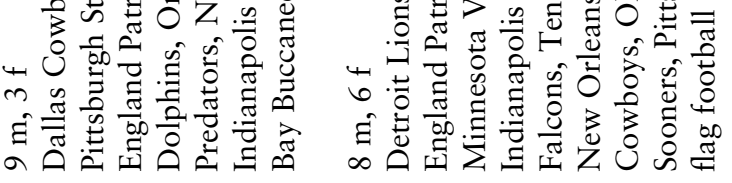

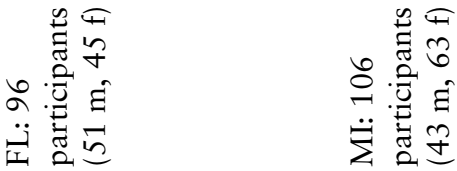

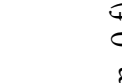

ఏ

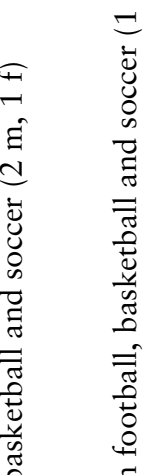

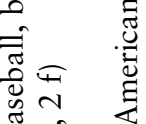

$\circ$ घ

tक 0

0 एँ

घ)

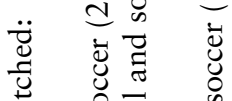

范

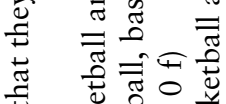

\& $\frac{1}{\tilde{0}}$ है ही

욜

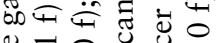

हैं छी

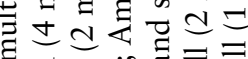

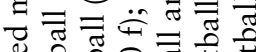

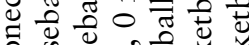

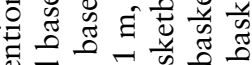

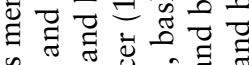

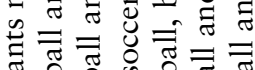

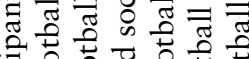

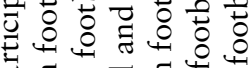

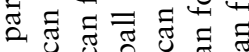
น.

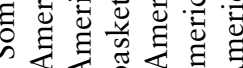

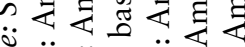

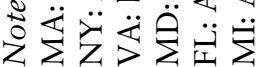


then African American'), said, 'I really love basketball. I don't like regular football, but I like flag football. I love Cleveland Cavaliers (basketball) and my favourite player is LeBron James' (interview, Michigan, May 2010). As discussed earlier (e.g. in Adam's case), in some cases African Americans take great pride in connecting themselves with African American sportspersons.

Sport helps to resolve difference between colour, race, creed and class. It is normally in the sports field that one can see a black sitting beside a white, a Muslim beside a non-Muslim, all cheering for their respective teams. In outlining the role of sport in the identity-making process, Jeremy MacClancy observed that through particular forms of expression, sport helps to define a community. And sport provides people with a sense of other people's social identity. ${ }^{68}$ Some people's identity may be already established but, when they show their passion for a particular sport or sports, they reflexively take on an additional identity, which for hardcore fans may be their primary identity.

David Ogden and Michael Hilt noted that most African Americans preferred basketball because it has become a part of their culture, giving them a sense of collective identity. Almost 80 per cent of American basketball players in the NBA are black, compared to 13 per cent in major league baseball. Many more black youths than white youths are encouraged in schools to play basketball because it is seen as the 'best and shortest trip' out of their undesirable socioeconomic condition. And by seeing many black NBA players, black youths feel encouraged; it boosts their self-esteem and helps their social mobility. ${ }^{69}$ In this context, it is worth mentioning that President Obama plays basketball.

However, my study shows that basketball is not confined to an African American identity. Ninety-one (35 per cent) Muslim Americans of diverse backgrounds spoke highly of basketball (followed by American football; see Table 3.2) and many of them said that their favourite team was the Los Angeles Lakers and their favourite player Kobe Bryant. Ogden and Hilt observed that through basketball games both black and white youths develop a 'sense of cultural power' by wearing basketball apparel and Nike shoes (as worn by the players), thereby reinforcing their masculine identity. ${ }^{70}$ Basketball is not exclusive to masculine identity, however: thirty-one female participants said that it was their favorite sport (in some cases jointly with American football). My study also showed that the next preferred sport of Muslim Americans was American football. Participants who lived on the east coast (Massachusetts, New York, Maryland and Virginia) mostly preferred teams in their region, for example, the Patriots and the Redskins. In Florida and Michigan, the choice of team was varied, but some tended to support their local teams. The Super Bowl was a popular event among the sports lover participants in all states.

In the last 150 years, baseball has been considered America's 'national pastime' but it appears that basketball has gained supremacy worldwide, with approximately 450 million people playing the game, and, for the 2007-8 NBA 


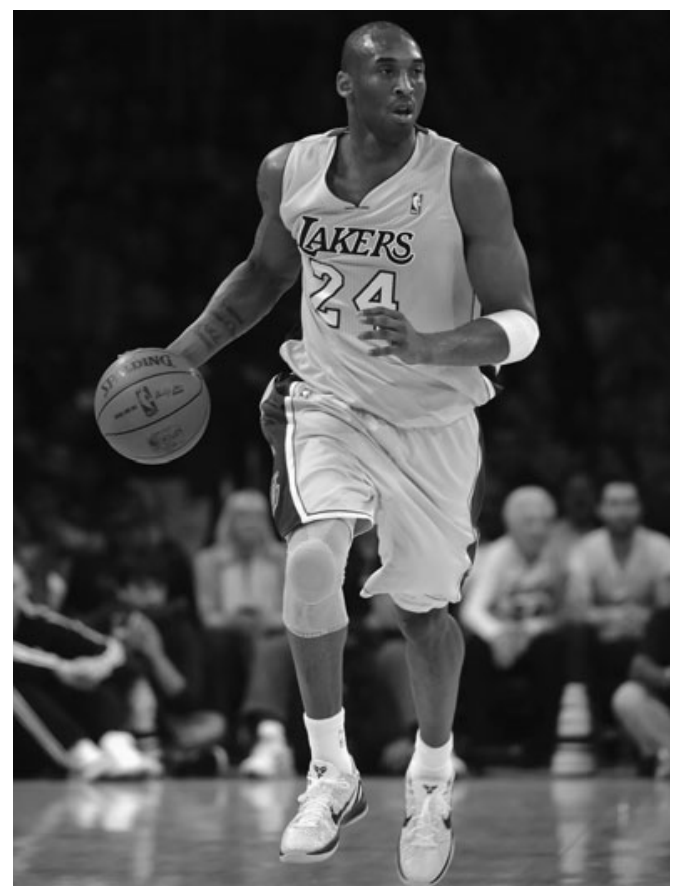

Figure 3.2 Kobe Bryant. Los Angeles Clippers v. Los Angeles Lakers, 25 March 2011. Result: Clippers 104, Lakers 112. Bryant scored 37 points. Lisa Blumenfeld/Getty Images Sport.

season, there were 1.76 billion TV viewers. In 2008-9, the Sporting Goods Manufacturers Association said (based on their recent survey) there were 25.9 million regular basketball players in America, making it the most played sport, with baseball and outdoor soccer ranked second and third. ${ }^{71}$

In my survey, the soccer fans (48) were more numerous than baseball fans (18) (see Table 3.2). I am not sure why such a variation exists among young Muslims. Perhaps soccer is more popular because it is also played in their country of origin, and watching soccer has become a cultural and family event. Whatever their ranking of sport, young peoples' involvement in any sport/ games should be viewed as 'cultural capital' (competence that is conducive to membership of a cultural community). Sport can impact on identity, and it is very important as a healing process and helping with the development of young Muslims' self-esteem.

\section{Conclusion}

As can be seen in this chapter, the identity responses of participants were varied: multiple, dual or hyphenated, collective and single. When participants 
discussed certain issues, either they spoke from their personal or lived experience or their opinions were based on observation. In most discussions, the topic of the 'media' popped up and this may have impacted on their identity. I agree with other social identity theorists that identity is always in motion, and that it is formed through various factors, such as heritage, social group, family and community environment, ingroup feelings, and recognition and approval from ingroups (Muslim community) and outgroups (wider society). When identity confronts an 'opposing self', the 'self' can crystallise instinctively, and when people see similarities their identity can polarise into a collective identity.

While interviewing the participants, I asked them about their hobbies or extracurricular activities and I found that most participants appeared to be bicultural (balanced with a foot in each culture), with their American identity often linked by participation in American sports (such as basketball). However, this chapter could serve as a cautionary tale for Muslims and the wider community to work together to address their impending issues, and to create a productive bicultural society for young citizens. This proposition will be discussed further in the concluding chapter.

\section{Notes}

1. Anthony D. Smith, National Identity (London: Penguin, 1991), pp. 11-15.

2. Kwame Anthony Appiah, The Ethics of Identity (Princeton, NJ: Princeton University Press, 2005), p. 116.

3. Selcuk R. Sirin and Michelle Fine, Muslim American Youth: Understanding Hyphenated Identities through Multiple Methods (New York: New York University Press, 2008), p. 3.

4. Joshua J. Yates, 'Making Sense of Cosmopolitanism: A Conversation with Kwame Anthony Appiah', Hedgehog Review, Fall 2009, pp. 42-50, at pp. 44-5.

5. Ibid., p. 45.

6. See Chapter 1 for detailed discussion. See also Jocelyne Cesari, When Islam and Democracy Meet: Muslims in Europe and the United States (New York: Palgrave Macmillan, 2004); Yvonne Yazbeck Haddad, Jane I. Smith and Kathleen M. Moore, Muslim Women in America: The Challenges of Islamic Identity Today (New York: Oxford University Press, 2006), p. 28; Selcuk R. Sirin and Michelle Fine, 'Hyphenated Selves: Muslim American Youth Negotiating Identities on the Fault Lines of Global Conflict', Applied Development Science 11:3 (2007), pp. 151-63; Yasmin Moll, 'Screening Faith, Making Muslims: Islamic Media for Muslim American Children and Politics of Identity', in Yvonne Yazbeck Haddad, Farid Senzai and Jane I. Smith (eds), Educating the Muslims of America (Oxford: Oxford University Press, 2009), pp. 155-77; Sally Howell and Amaney Jamal, 'The Aftermath of the 9/11 Attacks', in Detroit Arab American Study Team, Citizenship and Crisis: Arab Detroit after 9/11 (New York: Russell Sage Foundation, 2009), 
pp. 69-100; John L. Esposito, The Future of Islam (New York: Oxford University Press, 2010); Jane I. Smith, Islam in America, 2nd edn (New York: Columbia University Press, 2010).

7. Tony Gaskew, Policing American Muslim Communities: A Compendium of Post 9/11 Interviews (Lewiston, NY: Edwin Mellen Press, 2008); Louise Cainkar, Homeland Insecurity: The Arab American and Muslim American Experience after 9/11 (New York: Russell Sage Foundation, 2011).

8. The interviews were tape recorded. The anonymity of the participants is maintained.

9. Amartya Sen, Identity and Violence: The Illusion of Destiny (London: Allen Lane, 2006), pp. 4-5.

10. Ibid. p. 19.

11. Michael Roskin, Countries and Concepts: Politics, Geography, Culture, 11th edn (Boston: Pearson Longman, 2011).

12. See Roskin, Countries and Concepts, pp. 234, 335, 552. This phenomenon of stereotyping Muslims or Arabs in textbooks is not new. In 1971, when researching social studies textbooks used in schools in Ontario, authors McDiarmid and Pratt found the words most often used to describe Muslims were 'infidels', 'fanatical', 'great', 'devout' and 'tolerant', whereas the words used to describe Christians included 'devoted', 'zealous', 'martyr', 'great' and 'famous'. In a survey of elementary and junior high social science textbooks used in the Californian educational system, Ayad al-Qazzaz found that though the nomadic Bedouin life accounts for only 5 to 8 per cent of the total Arab population, in the textbooks this information is provided as something normal in Arab society. This generalisation about Arabs as Bedouin people impacted on the school students. Consequently, in a survey of 251 junior and senior high school students, al-Qazzaz found that more than half of them viewed Arabs as a desert people. See Baha Abu-Laban, 'The Canadian Muslim Community: The Need for a New Survival Strategy', in Earle H. Waugh, Baha Abu-Laban and Regula B. Qureishi (eds), The Muslim Community in North America (Edmonton: University of Alberta Press, 1983), pp. 75-92; Jacqueline S. Ismael and Tareq Y. Ismael, 'The Arab Americans and the Middle East', Middle East Journal 30:3 (1976), pp. 390-405.

13. Nahid Kabir, 'Representation of Islam and Muslims in the Australian Media, 2001-2005', Journal of Muslim Minority Affairs, 26:3 (2006), pp. 313-28, see pp. 314-15; Nahid Afrose Kabir, Young British Muslims: Identity, Culture, Politics and the Media (Edinburgh: Edinburgh University Press, 2010), p. 137.

14. Similar concern was expressed by Samuel Huntington in his book Who Are We? The Challenges to America's National Identity (New York: Simon \& Schuster, 2005) when he said that if the 'bilingual and bicultural society' was allowed to grow then the cultural identity of mainstream American Anglo-Protestants would be threatened. Huntington's earlier book, The Clash of Civilizations and the Remaking of World Order (New York: Simon \& Schuster, 1996), has generated a lot of controversy in academia for its antagonistic views towards Muslims.

15. Homi Bhabha, The Location of Culture (London: Routledge, 1994). 
16. Jonathan Rutherford, 'The Third Space: Interview with Homi Bhabha', in Jonathan Rutherford (ed.), Identity: Community, Culture, Difference (London: Lawrence and Wishart, 1990), pp. 207-21.

17. Anne Applebaum, 'Teddy bear tyranny', Washington Post, 4 December 2007, p. A21.

18. The desire of young Muslims to fit in with the wider society has been discussed by other scholars. For example see, Shabana Mir, “'I Didn't Want to Have That Outcast Belief about Alcohol”: Muslim Women Encounter Drinking Cultures on Campus', in Haddad, Senzai and Smith (eds), Educating the Muslims of America, pp. 209-30.

19. Michael Slackman, 'Iran's Guardian Council certifies Ahmadinejad election victory', New York Times, 30 June 2009, p. 4.

20. 'Controversial Elections', FairVote website, http://archive.fairvote.org/e_college/ controversial.htm, accessed 17 May 2012.

21. 'America Votes 2004', CNN website, http://us.cnn.com/ELECTION/2004/index. html, accessed 17 May 2012.

22. 'Ahmadinejad speaks; outrage and controversy follow', $\mathrm{CNN}$ website, 24 September 2007, http://edition.cnn.com/2007/US/09/24/us.iran/, accessed 17 May 2012.

23. Francesca Polletta and James M. Jasper, 'Collective Identity and Social Movements', Annual Review of Sociology 27 (2001), pp. 283-305, see pp. 285, 298.

24. Appiah, The Ethics of Identity, p. 107.

25. Black Power was a political movement that grew up in the 1950 s and 1960 s to express a new racial consciousness among African Americans. It sought to improve the economic conditions of the black community but did not encourage assimilation/integration with 'white' society. This movement led to the development of a 'black' identity but the negative side of this movement was that some African Americans resorted to violence. However, later it developed into the non-violent Civil Rights movement led by Martin Luther King. In 1964, President Lyndon B. Johnson signed the Civil Rights Act and in 1965 he signed the Voting Rights Act, thus granting emancipation to African Americans.

26. See Obiagele Lake, Blue Veins and Kinky Hair: Naming and Color Consciousness in African America (Westport, CT: Praeger, 2003); Richard Brent Turner, 'Constructing Masculinity: Interactions between Islam and African-American Youth since C. Eric Lincoln, The Black Muslims in America', Souls 8:4 (2006), pp. 31-44; Anita Jones Thomas and Sara Schwarzbaum, Culture and Identity: Life Stories for Counselors and Therapists (Thousand Oaks, CA: Sage, 2006), pp. 11-29.

27. See Obiagele Lake, 'Towards a Pan-African Identity: Diaspora of African Repatriates in Ghana', Anthropological Quarterly 68:1 (1995), pp. 21-36.

28. For example Richard Jenkins, Social Identity, 3rd edn (London: Routledge, 2008).

29. 'The Cat's comeback from rock star to Muslim devotee ...', Globe and Mail, 22 
May 2000, p. R1; see also Smith, Islam in America, pp. 175-6.

30. Ishan Bagby, Paul M. Perl and Bryan T. Froehle, The Mosque in America: A National Portrait - A Report from the Mosque Study Project (Washington, DC: Council on American-Islamic Relations, 2001), p. 21, cited in Turner, 'Constructing Masculinity', p. 32.

31. Turner, 'Constructing Masculinity', p. 40.

32. Jamillah A. Karim, 'To Be Black, Female, and Muslim: A Candid Conversation about Race in the American Ummah', Journal of Muslim Minority Affairs 26:2 (2006), pp. 225-33, see p. 229.

33. See for example, Jamillah Karim, American Muslim Women: Negotiating Race, Class and Gender within the Ummah (New York: New York University Press, 2009), pp. 43-4; Gaskew, Policing American Muslim Communities, pp. 118-27.

34. Amaney Jamal, 'Inside and Outside the Box: The Politics of Arab American Identity and Artistic Representations', paper prepared for 'The Role of the Arts in the United States', Immigrant Communities Working Meeting, Princeton University, 1-2 June 2006, pp. 3-4, http://cmd.princeton.edu/papers/wp0604a. pdf, accessed 24 May 2011. See also Andrew Shryock, 'The Moral Analogies of Race', in Amaney Jamal and Nadine Naber (eds), Race and Arab Americans before and after 9/11: From Invisible Citizens to Visible Subjects (Syracuse, NY: Syracuse University Press, 2008), pp. 81-113.

35. Nadine Naber, 'Ambiguous Insiders: An Investigation of Arab American Invisibility', Ethnic and Racial Studies 23:1 (2000), pp. 37-61, see p. 43.

36. Edward Said, Covering Islam: How the Media and the Experts Determine How We See the Rest of the World, rev. edn (London: Vintage, 1997); Yvonne Yazbeck Haddad, 'American Foreign Policy in the Middle East and Its Impact on the Identity of Arab Muslims in the United States', in Yvonne Yazbeck Haddad (ed.), The Muslims of America (New York: Oxford University Press, 1991), pp. 217-35; Caroline R. Nagel and Lynn A. Staeheli, 'Citizenship, Identity and Transnational Migration: Arab Immigrants to the United States', Space and Polity 8:1 (2004), pp. 2-23; Naber, 'Ambiguous Insiders'; Jamal, 'Inside and Outside the Box'; Shryock, 'The Moral Analogies of Race'; Haddad, Smith and Moore, Muslim Women in America.

37. Steven George Salaita, 'Ethnic Identity and Imperative Patriotism: Arab Americans before and after 9/11', College Literature 32:2 (2005), pp. 146-68.

38. Jenkins, Social Identity, pp. 112-13.

39. 'United States Armed Forces', Wikipedia, http://en.wikipedia.org/wiki/United_ States_Armed_Forces, accessed 24 May 2012.

40. 'Muslims already pray at Ground Zero', Korea Times website, 5 September 2010, http://www.koreatimes.co.kr/www/news/opinon/2012/05/160._72545.html, accessed 18 May 2012.

41. Laura Crimaldi, 'Many rally for alleged terrorist', Boston Herald, 13 November 2009, p. 3.

42. Stuart Hall, 'Introduction: Who Needs "Identity"?', in Stuart Hall and Paul du 
Gay (eds), Questions of Cultural Identity (London: Sage, 1996), pp. 1-17, see p. 4.

43. Henri Tajfel (ed.), Human Groups and Social Categories: Studies in Social Psychology (Cambridge: Cambridge University Press, 1981); Jenkins, Social Identity.

44. Elsa R. Germain, 'Culture or Race? Phenotype and Cultural Identity Development in Minority Australian Adolescents', Australian Psychologist 39:2 (2004), pp. 134-42, see p. 140.

45. Lukas Pleva, 'Glen Beck says President Obama is out of step with the nation on Arizona's immigration law', St Petersburg Times, 3 June 2010.

46. 'Say no to Arizona type profiling law in Michigan', Dawud Walid's blog, 28 February 2011, http://dawudwalid.wordpress.com/2011/02/28/say-no-to-arizonatype-profiling-law-in-michigan/, accessed 18 May 2012.

47. Randal C. Archibold, 'Arizona enacts stringent law on immigration', New York Times, 24 April 2010, p. 1.

48. 'Somali pirate on trial in US court', Institute for Security Studies website, 12 May 2009, http://www.iss.co.za/iss_today.php?ID=1197, accessed 18 May 2012.

49. Ron Scherer, 'What will US do with 15 Somali pirates after fatal hijacking?', Christian Science Monitor, 25 February 2011, http://www.csmonitor.com/USA/ Justice/2011/0225/What-will-US-do-with-15-Somali-pirates-after-fatal-hijacking, accessed 18 May 2012.

50. 'Baby Bin Ladens', Dominion Post, 8 January 2011, p. 21; David Usborne, 'Cries of McCarthyism over US Muslim hearing', The Independent, 11 March 2011, pp. 26-7.

51. Kabir, Young British Muslims, p. 98; Nazli Kibria, Muslims in Motion: Islam and National Identity in the Bangladeshi Diaspora (New Brunswick, NJ: Rutgers University Press, 2011), p. 72.

52. For similar views, see also Jasmin Zine, "Safe Havens or Religious "Ghettos"? Narratives of Islamic Schooling in Canada', in Haddad, Senzai and Smith (eds.), Educating the Muslims of America, pp. 39-66.

53. Avtar Brah, 'Non-binarized Identities of Similarity and Difference', in Margaret Wetherell, Michelynn Laflèche and Robert Berkeley (eds), Identity, Ethnic Diversity and Community Cohesion (London: Sage, 2007), pp. 136-45, see pp. 144-5.

54. Declan Walsh, 'Explosives plot: neuroscientist was at heart of al-Qaida cell, files claim', The Guardian, 26 April 2011, p. 7.

55. 'Raymond Davis and norms of justice', PakTribune website, 7 March 2011, http:// paktribune.com/articles/Raymond-Davis-and-Norms-of-justice-236956.html, accessed 24 May 2012.

56. 'Foreign funding in education intact: Rabbani', Daily Post (Lahore, Pakistan), 10 April 2011.

57. I discuss the points raised by Faizul, such as the fact that the media did not label the Christian militia that planned to attack the police force as 'terrorists', in detail in Chapter 4. I discuss the civilian casualties in Afghanistan and Iraq and the 
Guantánamo Bay ordeal in Chapter 6.

58. George Hunter and Doug Guthrie, 'Detroit imam autopsy raises ire', Detroit News, 2 February 2010, p. 3.

59. Zeenath Kausar, 'Communal Riots in India: Hindu-Muslim Conflict and Resolution', Journal of Muslim Minority Affairs 26:3 (2006), pp. 353-70, see p. 359.

60. See also Helen Carter, Rory McCarthy and Rebecca Allison, 'British journalist freed', The Guardian, 9 October 2001, p. 1.

61. Kabir, Young British Muslims, pp. 64-6, 78; see also Smith, Islam in America, pp. 139-44.

62. Esposito, The Future of Islam, p. 30.

63. Andrew Parker and John Harris, 'Introduction: Sport and Social Identities', in John Harris and Andrew Parker (eds), Sport and Social Identities (Basingstoke: Palgrave Macmillan, 2009), pp. 1-14, see pp. 3-4.

64. Tony Schirato, Understanding Sports Culture (Los Angeles: Sage, 2007), see p. 17.

65. Samaya Farooq and Andrew Parker, 'Sport, Religion and Social Identity: Physical Education and Muslim Independent Schooling', in Harris and Parker (eds), Sport and Social Identities, pp. 109-31.

66. Ibid., p. 121.

67. Kabir, Young British Muslims.

68. Jeremy MacClancy (ed.), Sport, Identity and Ethnicity (Oxford: Berg, 1996), pp. 2-3, cited in Parker and Harris (eds), Sport and Social Identities, pp. 6-7.

69. David C. Ogden and Michael L. Hilt, 'Collective Identity and Basketball: An Explanation for the Decreasing Number of African-Americans on America's Baseball Diamonds', Journal of Leisure Research 35:2 (2003), pp. 213-27, see pp. 217-22.

70. Ibid., p. 221.

71. Bryan Curtis, 'The national pastime(s)', New York Times, 1 February 2009, p. 5. 